\title{
Recurrent explosive eruptions from a high risk Main Ethiopian Rift volcano throughout the Holocene
}

C. M. Martin-Jones ${ }^{1,2}$, C. S. Lane ${ }^{2}$, N. J. G. Pearce ${ }^{1}$, V. C. Smith ${ }^{3}$, H. F. Lamb ${ }^{1}$, F. Schaebitz ${ }^{4}$ F.Viehberg $^{5}$, M.C. Brown ${ }^{6,7}$, U. Frank ${ }^{7} \&$ A. Asrat ${ }^{8}$

*Correspondence to: Catherine.Martin-Jones@geog.cam.ac.uk

\section{SUPPLEMENTARY MATERIALS}

\section{Materials and Methods}

DR1 a. Lake core and proximal tephras

Table DR1 Locations and details of lake sediment cores, proximal tephras and obsidian samples.

\begin{tabular}{|c|c|c|c|c|c|c|}
\hline Site & Core name & Latitude & Longitude & $\begin{array}{l}\text { Collection } \\
\text { date }\end{array}$ & $\begin{array}{l}\text { Water } \\
\text { depth (m) }\end{array}$ & $\begin{array}{l}\text { Core } \\
\text { length (m) }\end{array}$ \\
\hline Tilo & Tilo97-1 & $7^{\circ} 5^{\prime} 46.71 " \mathrm{~N}$ & $38^{\circ} 5^{\prime} 26.23^{\prime \prime} \mathrm{E}$ & 1997 & 10 & 18 \\
\hline Awassa & Aw-94 & $7^{\circ} 2^{\prime} 44.46^{\prime \prime} \mathrm{N}$ & $38^{\circ} 26^{\prime} 54.10^{\prime \prime} \mathrm{E}$ & 1995 & 12 & 12 \\
\hline Chamo & CHA-01-2010 & $5^{\circ} 52^{\prime} 26.92^{\prime \prime} \mathrm{N}$ & $37^{\circ} 32^{\prime} 52.32^{\prime \prime} \mathrm{E}$ & 2010 & 14 & 14.3 \\
\hline \multicolumn{7}{|l|}{$\begin{array}{l}\text { Proximal } \\
\text { samples }\end{array}$} \\
\hline Sample ID & Sample area & Latitude & Longitude & Volcano & $\begin{array}{l}\text { Sample } \\
\text { type }\end{array}$ & $\begin{array}{l}\text { Age } \\
\text { estimate }\end{array}$ \\
\hline ST-NW 1 & Lake Awassa: Shallo Swamp & $7^{\circ} 3^{\prime} 11.70^{\prime \prime} \mathrm{N}$ & $38^{\circ} 32^{\prime} 57.03^{\prime \prime} \mathrm{E}$ & Corbetti & Pumice & $<2.3 \mathrm{ka}^{[3]}$ \\
\hline E950010 & $\begin{array}{l}\text { Lake Awassa: northern shore } \\
\text { promontory }\end{array}$ & $7^{\circ} 7^{\prime} 48.29 " \mathrm{~N}$ & $38^{\circ} 26^{\prime} 48.33^{\prime \prime} \mathrm{E}$ & Corbetti & Obsidian & Holocene \\
\hline E950011 & $\begin{array}{l}\text { Lake Awassa: northern shore } \\
\text { promontory } \\
\text { Lake Awassa: hill on northern }\end{array}$ & $7^{\circ} 7^{\prime} 48.29 " \mathrm{~N}$ & $38^{\circ} 26^{\prime} 48.33^{\prime \prime} \mathrm{E}$ & Corbetti & $\begin{array}{l}\text { Weathered } \\
\text { obsidian }\end{array}$ & Holocene \\
\hline E950019 & shore & $7^{\circ} 8^{\prime} 14.51 " \mathrm{~N}$ & $38^{\circ} 26^{\prime} 32.30^{\prime \prime} \mathrm{E}$ & Corbetti & Obsidian & Holocene \\
\hline
\end{tabular}

Details of all studied lake sediment cores are given in Table DR1. Sediments were cored from lakes Tilo, Awassa and Chamo as part of a long term collaborative study between Aberystwyth and Addis Ababa Universities and the University of Cologne. To ascertain the volcanic source of the tephra layers deposited in the three lakes, obsidian and tephras samples were collected from within the Corbetti Caldera for compositional analyses. The Chabbi obsidian and the Wendo Koshe Pumice were sampled from within the Corbetti Caldera by N. J. G. Pearce during field campaigns in 1995 and 1996.

$\underline{\mathrm{S} 1 \mathrm{~b} . \text { Visible tephra sampling and cryptotephra identification }}$

Visible tephras in the Tilo and Awassa sediments were recorded. Tephras samples, collected from the full thickness of the layers, were then wet sieved to $90-250 \mathrm{~mm}$ and dried. However, we could no longer define the original tephrostratigraphy described by Telford et al. (1999) and were only able to sample and analyse three tephras. To investigate tephras dispersal, the Chamo sediments were investigated to identify cryptotephras - far travelled, typically dilute and fine grained tephras which are indistinguishable from the host sediments(Lane et al., 2014; Davies, 2015). To locate cryptotephras, standard extraction methods(Blockley et al., 2005) were followed. Due to sample availability and time constraints, sediments were sampled for cryptotephra between $502-920 \mathrm{~cm}$ depth $(0.5-4.5 \mathrm{cal}$. ka BP). Contiguous and continuous $2 \mathrm{~cm}$ samples across these intervals were dried and weighed. Samples were treated with $1 \mathrm{M} \mathrm{HCL}$ to remove carbonates, sieved to $>25 \mu \mathrm{m}$ and density separated using sodium polytungstate, to $1.95-2.55 \mathrm{~g} / \mathrm{cm}^{3}$. Extracted glass shards were then counted using a transmitted light microscope. Primary cryptotephra deposits are typically characterised by a rapid increase in shard counts which declines upwards through the stratigraphy(Lane et al., 2014). Samples for geochemical analysis were taken at the depth of the initial increase in shard counts in the stratigraphy (S2a).

\section{$\underline{\text { S1 c Glass compositional analysis }}$}

Shards from visible and cryptotephras were mounted in epoxy resin; ground and polished. Single grain major and minor element concentrations were measured using a JEOL 8600 wavelength dispersive electron microprobe (EMP) at the Research Laboratory for Archaeology and the History of Art, University of Oxford. To reduce alkali migration in the glass a defocussed beam with a 10 $\mu \mathrm{m}$ diameter, $15 \mathrm{kV}$ accelerating voltage and $6 \mathrm{nA}$ current was used. Na was counted first, for $10 \mathrm{~s}, \mathrm{Cl}$ and $\mathrm{P}$ were collected for 60 
$\mathrm{s}$ and other major elements were collected for $30 \mathrm{~s}$. A suite of mineral standards were used to calibrate the instrument and the MPI-DING volcanic glasses(Jochum et al., 2006) were used as secondary standards. All analyses presented in the text, tables and graphs have been normalised to an anhydrous basis, to remove any effects of the variable secondary hydration of glasses. The raw glass analyses are given in the supplementary data (S2 b). Trace element compositions of single glass shards were determined using laser ablation (LA) ICP-MS at Aberystwyth University. Analyses were performed using a Coherent GeoLas ArF $193 \mathrm{~nm}$ Excimer laser coupled to a Thermo Finnigan Element 2 ICP-MS; with a laser energy of $10 \mathrm{~J} \mathrm{~cm}^{2}$, repetition rate of $5 \mathrm{~Hz}$ and $24 \mathrm{~s}$ acquisition time. ${ }^{29} \mathrm{Si}$ was used as the internal standard, the $\mathrm{SiO}_{2}$ having previously been determined by EPMA. Trace element concentrations ( $\mathrm{ppm}$ ) were calculated by comparing the analyte isotope intensity/internal standard intensity in the shard to the same ratio in the NIST SRM 612 reference material using published concentrations from Pearce et al.(Pearce et al., 1996) Analyses using $<20 \mu \mathrm{m}$ spot sizes were corrected for variations in element fractionation(Pearce et al., 2011, 2014). The rhyolitic MPI-DING reference material, ATHO-G, was analysed during each analytical run to monitor accuracy and precision, and analyses are given in $\mathrm{S} 2 \mathrm{~b}$.

\section{$\underline{\text { S1 d Chronology }}$}

In order to investigate the timing of past volcanism, age models were constructed for the Tilo, Awassa and Chamo sediments. Seven published dates(Telford and Lamb, 1999) on grass charcoal fragment provide the chronology for the Tilo97-1 archive. Four published dates(Telford et al., 1999), determined on bulk sediments provide the chronology for the Awassa Aw-94 archive. Nine radiocarbon dates, including seven ages from Kassa (2013), on plant and shell fragments give the chronology for the Chamo CHA-01-2010 core.

Prior to AMS analysis, samples were pretreated using conventional procedures(Rethemeyer et al., 2013). To remove carbonates, sediment samples were treated with $\mathrm{HCl}$ and charcoal samples were treated with a further $\mathrm{NaOH}$ wash to remove secondary organic acids. Sample carbon was then converted to graphite and measured at Beta- Analytic (Tilo and Awassa) and CologneAMS(Rethemeyer et al., 2013) (Chamo).

OxCal version 4. 2(Bronk Ramsey and Lee, 2013) was used to generate Bayesian P_Sequence depositional models(Bronk Ramsey, 2008) for the archives (Figs. DR1 and DR2), using the IntCal13(Reimer et al., 2013) calibration curve. Prior to analysis, sediment core depths were converted to event free depths by excluding tephra layers of $>0.5 \mathrm{~cm}$ thickness. Interpolated tephra age ranges were retrieved using the Date function and are herein quoted to $68.2 \%$ confidence levels. OxCal P_Sequence parameters and code for each age model is given below. Only the lower part of the Chamo sequence below $470 \mathrm{~cm}$, that is constrained by radiocarbon age estimates and corresponds to the section where tephra/cryptotephra were recovered, was modelled in OxCal. Two dates (COL2454 and COL2455) from $865.5 \mathrm{~cm}$ depth in the CHA-01-2010 archive have been combined using the $R \_$Combine function. Sediment deposition rates are typically constant within the age model, however beneath $470.5 \mathrm{~cm}$ depth $(766-882 \mathrm{cal}$. a BP) sedimentation rates increased significantly. The modelled age-estimate for CHT-2 is not bounded by a lower (older) ageestimate in the model, meaning that the sedimentation rate at this point in the sequence is not fully constrained. For this reason, the age-estimate for CHT-2 is considered less robust that the age for CHT-1. 
Table DR2 AMS ${ }^{14} \mathrm{C}$ measurements for the Awassa, Tilo and Chamo sediments cores. Ages were calibrated using IntCal13(Reimer et al., 2013) run in OxCal version 4.2(Bronk Ramsey, 2009). Seven radiocarbon ages (*) on the Chamo sediments are from Kassa(Kassa, 2013). Two dates (COL2454 and COL2455) from $865.5 \mathrm{~cm}$ depth in the CHA-01-2010 archive have been combined using the $R \_$Combine function.

\begin{tabular}{|c|c|c|c|c|c|}
\hline $\begin{array}{l}\text { Sample number } \\
\text { Awassa }\end{array}$ & $\begin{array}{l}\text { 14C age yr } \\
\mathrm{BP}( \pm 1 \sigma)\end{array}$ & $\begin{array}{l}\text { Depth } \\
\text { (cm) }\end{array}$ & $\begin{array}{l}\delta^{13} C \\
(\% o \\
\text { PDB) }\end{array}$ & $\begin{array}{l}\text { Calibrated } \\
\text { ages BP }\end{array}$ & $\begin{array}{l}\text { Dated } \\
\text { material }\end{array}$ \\
\hline Beta-100436 & $1450 \pm 80$ & 259 & -20.9 & $1515-1290$ & Bulk \\
\hline Beta-100437 & $3180 \pm 90$ & 522 & -19.9 & $3558-3340$ & Bulk \\
\hline Beta- 81512 & $4500 \pm 110$ & 687.5 & -19.5 & $5187-4848$ & Bulk \\
\hline Beta-81513 & $6270 \pm 130$ & 1132.5 & -24.4 & $7420-7074$ & Bulk \\
\hline \multicolumn{6}{|l|}{ Tilo } \\
\hline Beta-106145 & $1390 \pm 50$ & 180 & -15.9 & $1345-1279$ & Charcoal \\
\hline Beta-106146 & $2400 \pm 50$ & 347 & -15.9 & $2675-2350$ & Charcoal \\
\hline Beta-106147 & $4140 \pm 60$ & 594.5 & -19.1 & $4816-4574$ & Charcoal \\
\hline Beta-90886 & $5520 \pm 80$ & 804 & -18.1 & $6399-6212$ & Charcoal \\
\hline Beta-106148 & $6880 \pm 50$ & 1289.5 & -17.3 & $7762-7664$ & Charcoal \\
\hline Beta-90887 & $7930 \pm 90$ & 1764 & -21.1 & $8954-8274$ & Charcoal \\
\hline Beta-106149 & $8840 \pm 50$ & 2316.5 & -15.6 & $10155-9834$ & Charcoal \\
\hline \multicolumn{6}{|l|}{ Chamo } \\
\hline COL3249 & $921 \pm 35$ & 470.5 & & $882-766$ & Plant/wood \\
\hline COL1244* & $1240 \pm 31$ & 639 & & $1271-1210$ & Plant \\
\hline COL3250 & $1398 \pm 47$ & 646.5 & & $1335-1279$ & Plant/wood \\
\hline COL1246* & $1489 \pm 81$ & 664 & & $1411-1301$ & Plant \\
\hline COL2454* & $3083 \pm 34$ & 865.5 & & $3445-3382$ & Ostracod \\
\hline COL2455* & $3304 \pm 37$ & 865.5 & & 3445 - 3382 & Plant \\
\hline COL1240* & $4081 \pm 24$ & 986 & & $4567-4450$ & Shell \\
\hline COL1241* & $3978 \pm 48$ & 987 & & $4571-4450$ & Shell \\
\hline COL1247* & $6578 \pm 34$ & 1289 & & $7498-7434$ & Plant \\
\hline
\end{tabular}


OxCal Code for the Tilo 97-1 sediment core

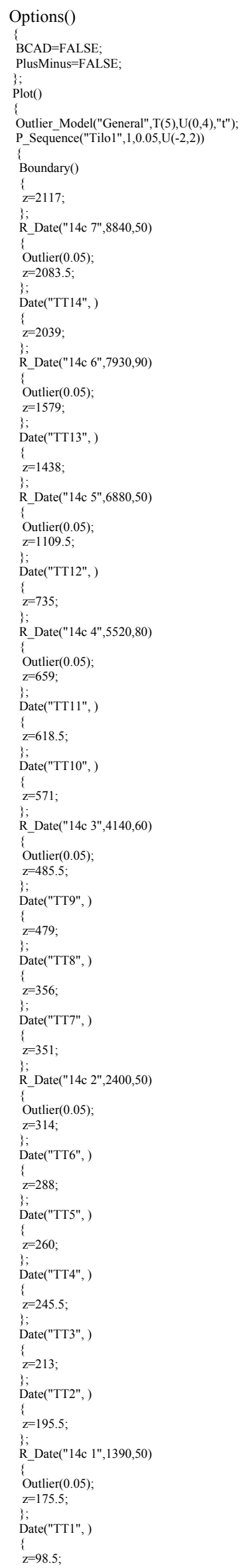




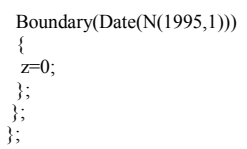

OxCal code for the Awassa AW-94 sediment core

Options)

BCAD=FALSE;

PlusMinus=FALSE;

;

Outlier_Model("General",T(5),U(0,4),"t");

P_Sequence("'", 1,0.1,U(-2,2))

Boundary()

$\{=1068.5$

Y;

R_Date("14c 4",6270,130)

Outlier(0.05);

$\mathrm{z}=1025.5$;

Date("AWT5")

$\mathrm{z}=980$;

Date("AWT4")

$\mathrm{z}=827$;

Date("AWT3")

z=790;

R Date("14c 3",4500,110)

Outlier(0.05);

$\mathrm{z}=669.5$;

Date("AWT2")

$\sum_{\mathrm{z}=532 ;}$

t-

R_Date("14c 2",3180,90)

Outlier(0.05);

$\mathrm{z}=508$;

R_Date("14c 1",1450,80)

Outlier(0.05);

$\mathrm{z}=245$;

Date("AWT1")

z=239;

$\mathrm{z}=239$

Boundary()

$\mathrm{z}=0$;

\}$;$

\}

OxCal code for the Chamo CHA-01-2010 sediment core

Options()

BCAD=FALSE

PlusMinus=FALSE;

\};

Outlier Model("General",T(5),U(0,4),"t");

P_Sequence("'",1,0.2,U(-2,2))

Boundary()

\{

$\mathrm{z}=1429$

Date("CHT2")

$\mathrm{z}=1360$;

R_Date("COL1247",6578,34)

Outlier(0.05);

$\mathrm{z}=1289$;

R_Date("COL1241",3978,48)

Outlier(0.05);

$\mathrm{z}=987$;

R_Date("COL1240",4081,24)

Outlier(0.05);

$\mathrm{z}=986$;

Date("D2")

\{ 


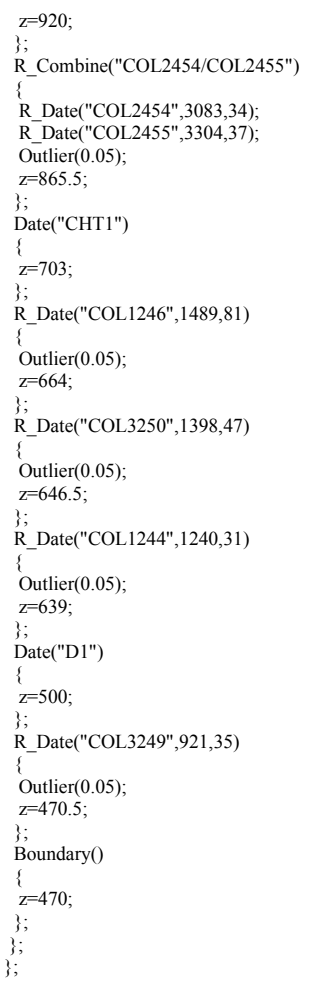




\section{$\underline{\text { S1 e Estimating recurrence rates }}$}

We used the Tilo tephra record to calculate the frequency of Corbetti's eruptions over the last $10 \mathrm{kyr}$. The Tilo tephra layers are stratigraphically and geochemically distinct, and we therefore infer each horizon represents an individual eruption.

Return intervals were calculated according to the methods described in Connor et al. $(2003,2006)$. The eruption record was tested for stationarity using a Kolmo-Smirnov test (Fig DR1a), showing the rate of events did not deviate from a steady-state within the 95\% confidence intervals. Repose intervals (the time between two successive eruptions) were then used in a Kaplan-Meier estimate (Dzierma and Wehrmann, 2012) to generate empirical survival function, which gives the probability that an observed repose interval will exceed a given time interval (Fig. DR1b).

$$
S_{T}(t)=P[T>t] \quad(\text { equation } 1)
$$

where $S_{T}$ gives the probability $(P)$ that an observed repose interval $(T)$ exceeds a given time interval $(t)$

$$
\mathrm{S}\left(\mathrm{t}_{i}\right)=\frac{N-i}{N} N \quad i=1, \ldots, N, \quad \text { (equation 2) }
$$

where $N$ is the total number of repose intervals and $i$ refers to the $i$ th repose interval in a ordered list from oldest to youngest

interval.
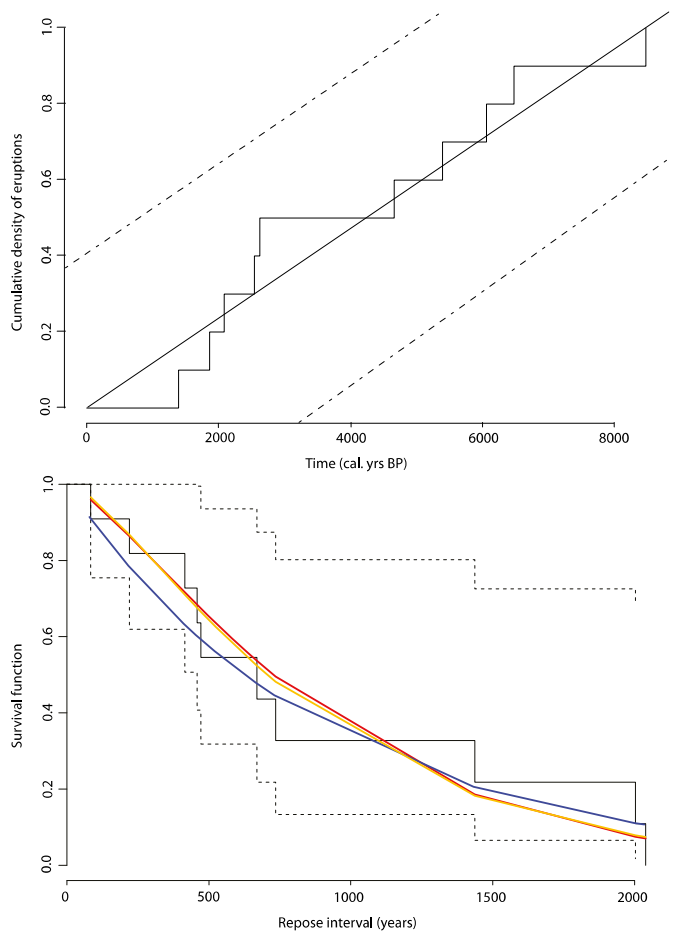

Fig. DR1. (a) Cumulative frequency of eruptions recorded as tephra horizons in the Lake Tilo sediment core over the last 10 kyrs. The rate of eruptions does not vary outside $95 \%$ confidence intervals (dashed lines) on the steady-state model (solid line). (b) Kaplan-Meier estimate of the survivor function, with Exponential (blue), Weibull (red) and Loglogistic (yellow) models fitted to the data.
Mid-points of the Tilo tephra age ranges from Bayesian age modeling were used for the calculations, thus any interpretations should consider this inherent age-uncertainty. A series of parametric models were fit to the Kaplan-Meier survival function using Flexsurv in R version 3.1.0, following Swindles et al. (2011); Dzierma and Wehrmann (2012) and Connor et al. (2006). On the basis of log likelihood and Akaike Information Criterion (Akaike, 1998) the eruption frequency is best described by the Weibull and Loglogistic models.

We calculate an average return rate of $\sim 900 \pm 220$ yrs (discounting the time since the most recent event), roughly comparable to the $\sim 1000$ year periodicity of eruptions from neighboring Alutu over the past $10 \mathrm{kyr}$ (Hutchison et al., 2016). The Kaplan-Meier test shows that within any 500 year period, there may be a $35 \%$ chance of an eruption (Fig. DR1b). 
$\underline{\text { S1 f Tephra volume calculation }}$

Illustrative isopachs for the Wendo Koshe Younger Pumice (WKYP) were drawn on the basis of the correlations between TT-2 and CHT-1 and published(Rapprich et al., 2016) thicknesses of the WKYP outcropping within the Corbetti caldera. These isopachs are idealised and, for simplicity, do not take wind direction into account. We used the exponential thinning model (Pyle, 1989; Fierstein and Nathenson, 1992) (equation 3) to generate a $\log ($ thickness) versus square root of area plot and estimate tephra thickness at the source $\left(\mathrm{T}={ }_{0}\right)$.

$$
\ln T=\ln T_{o}-k A^{1 / 2} \text { (equation 3) }
$$

Where $T$ is the tephra thickness, $T_{o}$ is the thickness at source and $A$ is the area of tephra deposition. The slope, $k$, can be calculated from a plot of $\ln (T)$ vs $A^{1 / 2}$ and can be extended back to estimate the thickness at source.

Using the calculate $K$ and $T_{O}$ values, the thickness half-distance $\left(b_{T}\right)$ and volume were calculated.

$$
\begin{gathered}
b_{T}=\ln (2) / k \sqrt{\pi} \quad \text { (equation 4) } \\
V=13.08 T_{o} b_{T}^{2} \quad \text { (equation 5) }
\end{gathered}
$$

\section{Supplementary 2: Data}

DR2 a Tephrostratigraphy:

The tephrostratigraphy of the Tilo, Awassa and Chamo lake sediments is given in Table DR3 and shown in Figures DR2 and DR3. 
Table DR3 List of tephra layers found in sediment cores from lakes Tilo, Awassa (based on the initial tephrostratigraphy described by Telford (1998) and Lamb (2000)) and Chamo, including their physical properties and Bayesian modeled ages (at $68.2 \%$ confidence intervals). Depth values are given for the base of each tephra layer.

\begin{tabular}{|c|c|c|}
\hline & $\begin{array}{l}\text { Composite } \\
\text { depth of the }\end{array}$ & Thickness \\
\hline Tephra ID & base (cm) & $(\mathrm{cm})$ \\
\hline
\end{tabular}

\section{Tephra description}

Modeled age (cal.

${ }^{14}$ C yrs BP)

Tilo

$\begin{array}{llllr}\text { TT-1 } & 103 & 4.5 & \text { Reverse-graded, coarse ash } & 1280-460 \\ \text { TT-2 } & 220 & 20 & \text { Discontinuous fine-coarse ash } & 1526-1263 \\ \text { TT-3 } & 238 & 0.5 & \text { Fine-coarse ash } & 1773-1276 \\ \text { TT-4 } & 272.5 & 2 & \text { Fine-coarse ash } & 2368-1365 \\ & & & & 2462-1711 \\ \text { TT-5 } & 292 & 5 & \text { Reverse-graded, fine-coarse ash } & 2672-2159 \\ \text { TT-6 } & 321 & 1 & \text { Fine-coarse ash } & 3092-1998 \\ \text { TT-7 } & 385 & 1 & \text { Fine-coarse ash } & 3258-1998 \\ \text { TT-8 } & 427 & 37 & \text { Coarse ash and lapilli } & 4804-4530 \\ \text { TT-9 } & 588 & 38 & \text { Coarse ash } & 5932-4871 \\ \text { TT-10 } & 710 & 30 & \text { Fine-coarse ash } & 6386-5754 \\ \text { TT-11 } & 763.5 & 6 & \text { Coarse ash } & 6679-6291 \\ \text { TT-12 } & 915 & 35 & \text { Coarse ash and lapilli } & 8701-8275 \\ \text { TT-13 } & 1623 & 5 & \text { Coarse ash } & 10,098-9751 \\ \text { TT-14 } & 2272 & 48 & \text { Coarse ash } & \end{array}$

\begin{tabular}{lllll} 
Awassa & \multicolumn{5}{c}{ Coarse ash } & $1474-1250$ \\
AWT-1 & 253 & 14 & Coarse ash and lapilli & $3779-3435$ \\
AWT-2 & 550 & 4 & Coarse ash & $5934-5440$ \\
AWT-3 & 818 & 10 & Fine-coarse ash & $6190-5693$ \\
AWT-4 & 928 & 73 & Fine-coarse ash & $7150-6765$ \\
AWT-5 & 1087 & 6 & Fine-coarse ash & $>7420$ \\
AWT-6 & 1160.5 & 0.5 & Fine-coarse ash & $>7420$ \\
AWT-7 & 1189 & 24 & & $1919-1524$ \\
Chamo & & & & $8270-7783$
\end{tabular}


(a) Awassa AW-94 core chronology and lithology

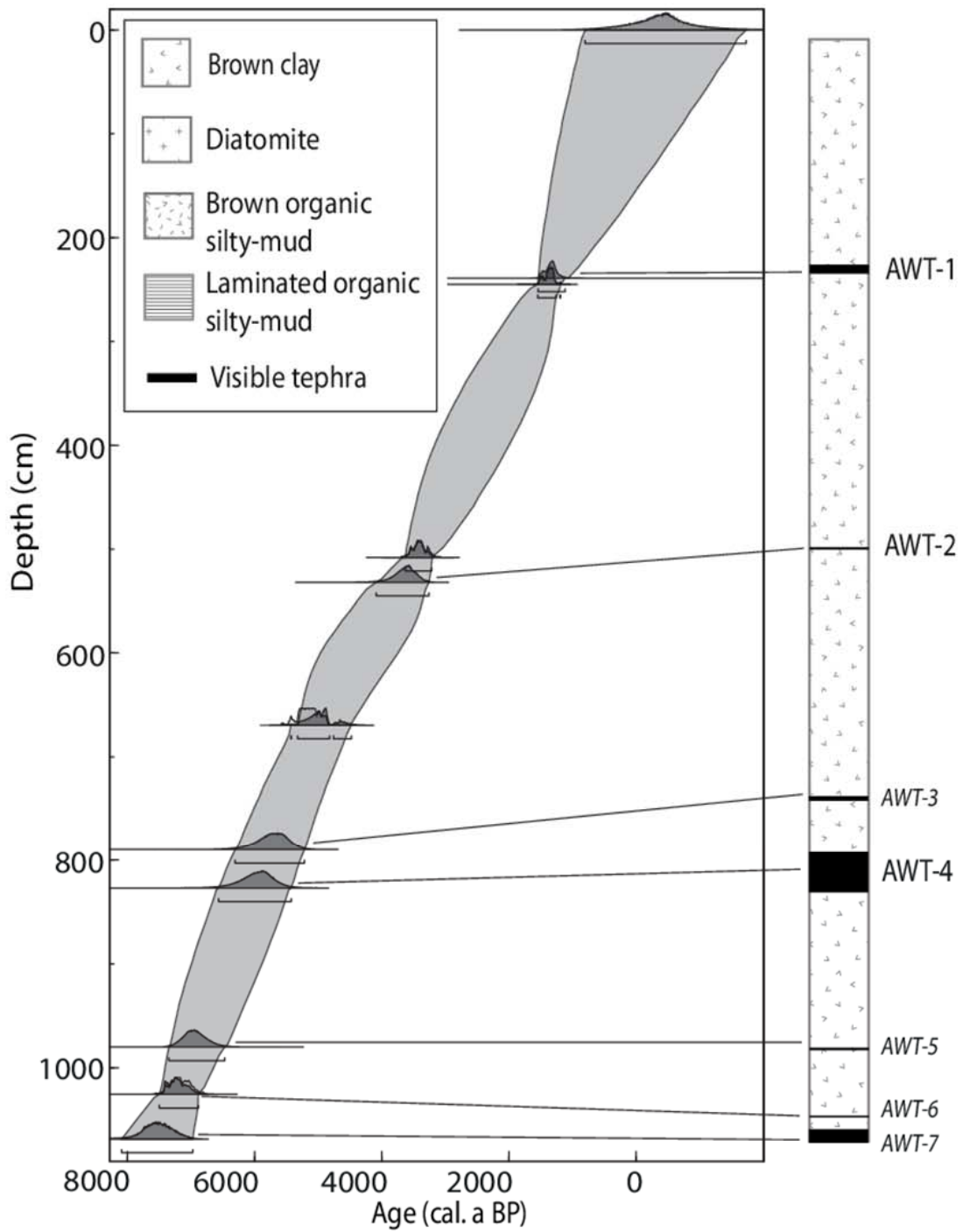

(b) Tilo 97-1 core chronology and lithology

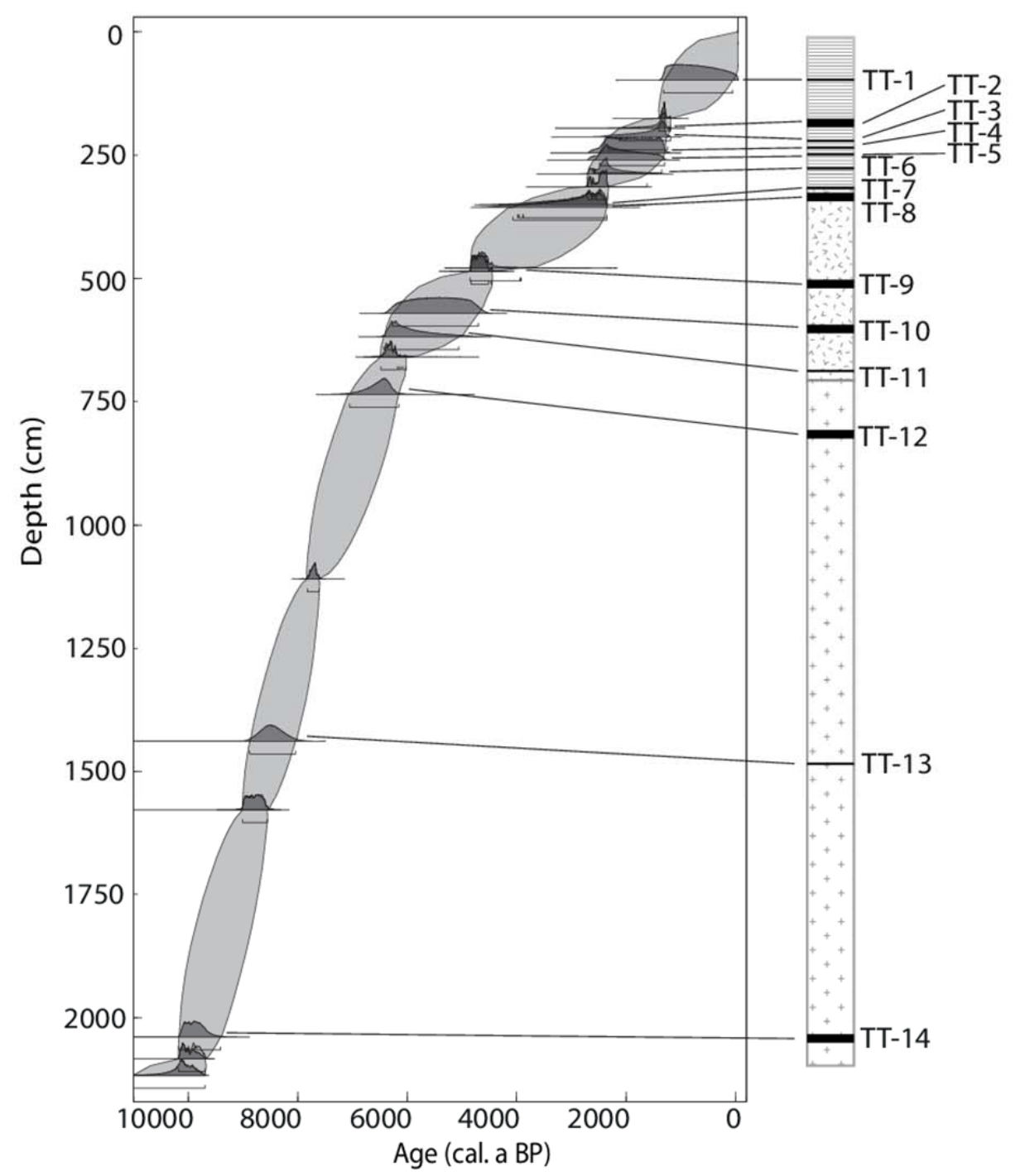

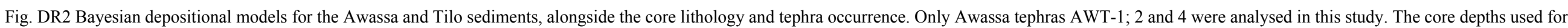
the age model are corrected for the presence of $>0.5 \mathrm{~cm}$ thick tephra layers, which are assumed to have been deposited instantaneously. 


\section{Chamo CHA-01-2010 core lithology, chronology and tephra glass shard concentrations}

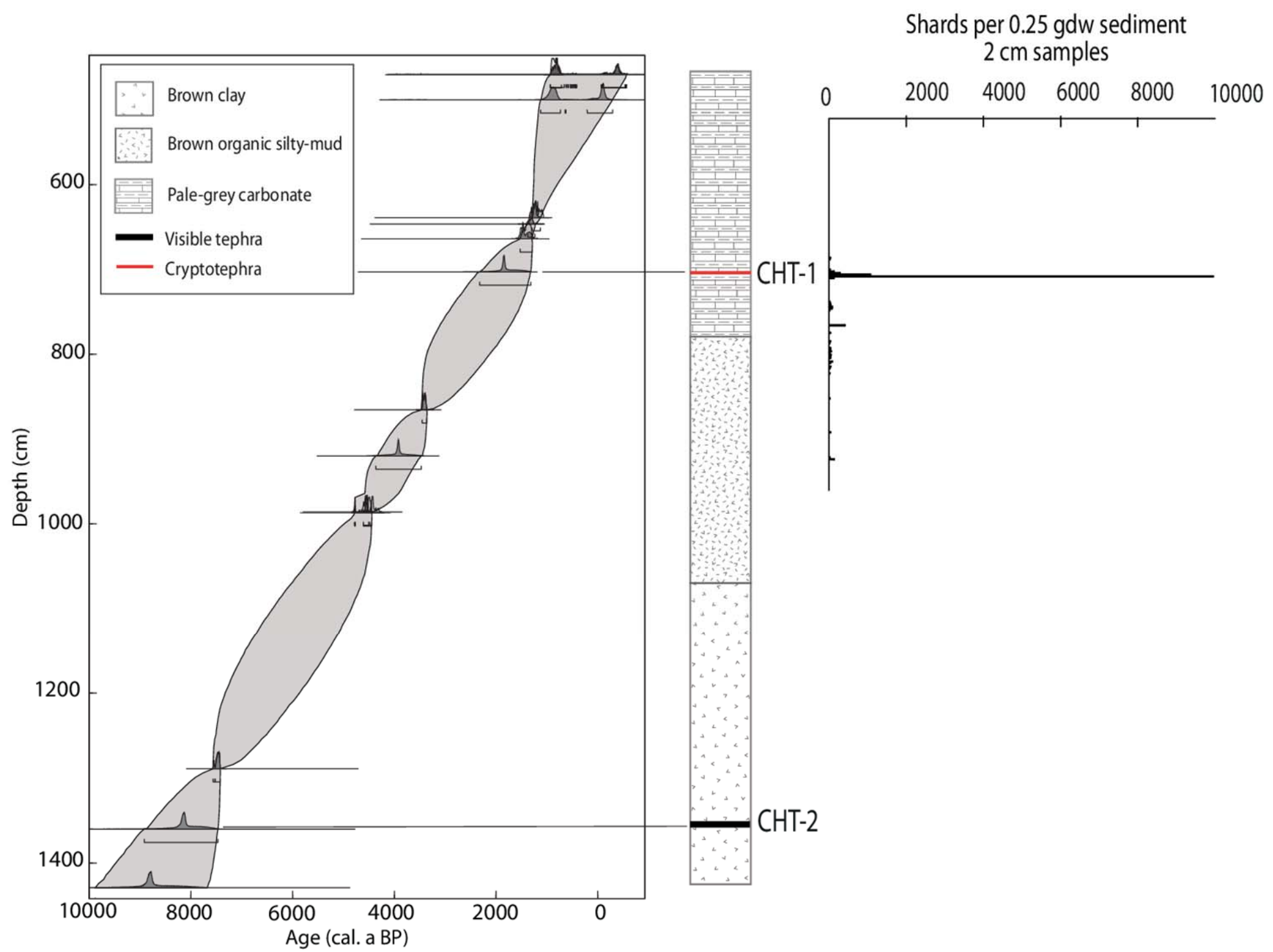

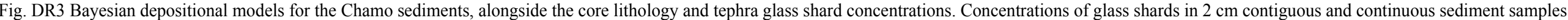

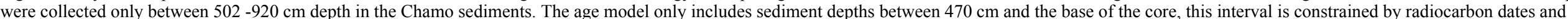
corresponds to the depths at which CHT-1 and CHT-2 occur. 
DR2 b Tephra compositions

Glass compositions of the lakes Awassa, Tilo and Chamo tephras are shown in Tables DR4 - DR7 and compared in Figs. DR4 - DR7. Tilo, Awassa and Chamo tephras are dominantly peralkaline rhyolites, however four shards are trachytic (Fig S3). The peralkaline tephras can be further classified as pantellerites $\left(\mathrm{Al}_{2} \mathrm{O}_{3}<1.33\left(\mathrm{FeO}^{\mathrm{T}}+4\right)\right.$.

(a)

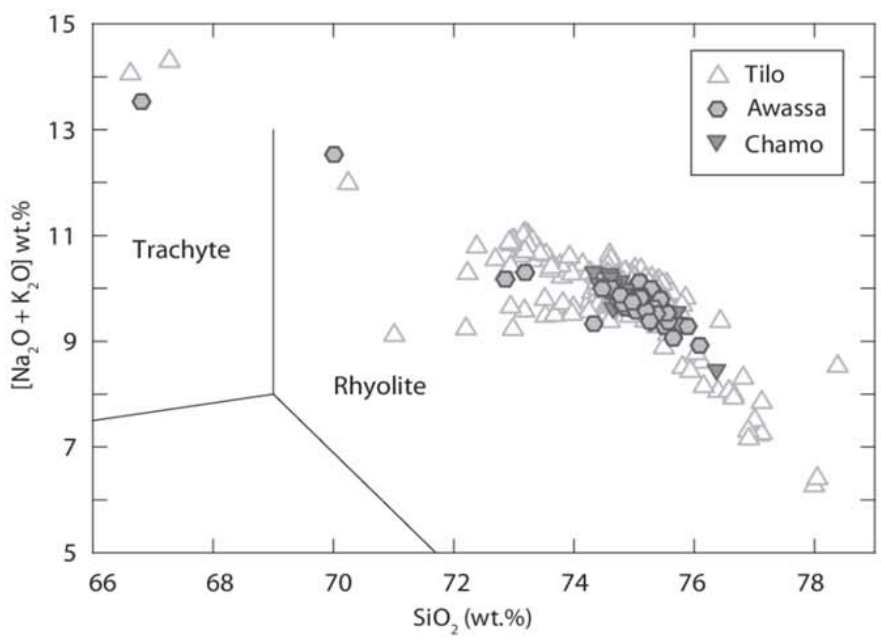

(b)

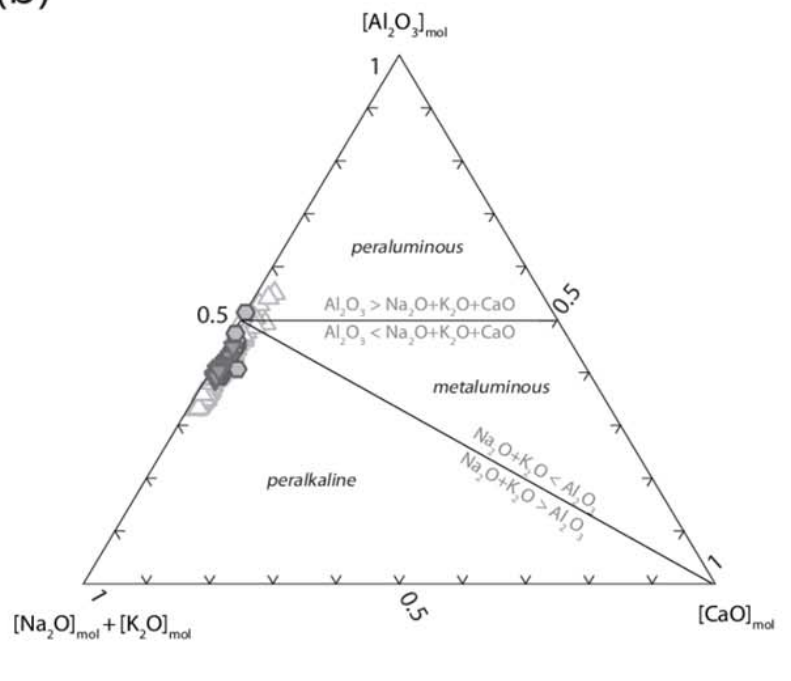

Fig. DR4 The Tilo, Awassa and Chamo tephras are rhyolitic, however three shards are trachytic. (b) The rhyolitic compositions can be further classified as peralkaline to peraluminous.

\section{Glass chemistry of the Lake Tilo tephras}

Variable glass compositions and $\mathrm{Zr} / \mathrm{Th}$ ratios divide the Tilo glass shards into two populations. Tephras TT-3 and TT-6 contain higher FeOT and Ba concentrations and lower $\mathrm{Zr} / \mathrm{Th}$ ratios $(55.9$ - 68.2) than all other Tilo tephras $(\mathrm{Zr} / \mathrm{Th} \sim 65.2-99.4$, Fig S5). This indicates that TT-3 and TT-6 glass shards are derived from a distinct volcanic source. All other Tilo tephras have similar glass compositions and $\mathrm{Zr} / \mathrm{Th}$ ratios and are co-genetic.

However, subtle inter-eruptive variations in $\mathrm{Y}, \mathrm{Zr}$, Ba and Th concentrations distinguish these tephras. Glass shards in the oldest Tilo tephras TT-11; 12; 13 and $14(10.1-5.8 \mathrm{cal}$ ka BP) contain the lowest Ba/Th ratios $(\sim 0.9-2.4)$ of the Tilo tephras (Fig. S5 c). TT-12 contains lower Y concentrations and TT-13 contains higher $\mathrm{FeO}^{\mathrm{T}}$ and $\mathrm{Zr}$ than glass shards in TT-11 and TT-14 (Fig. S9 b, d). Tephra glass shards in TT-1; $2 ; 4$ and $5(2.5-0.5$ cal ka BP) contain higher Ba/Th ratios $(\sim 2.6-4.1)$ that most glass shards in older tephras (Fig. S8 c). Only TT-1 and TT-2 glass shards can be distinguished, containing broadly higher concentrations of Ba than TT-4 and TT-5 (Fig. S8 c). Tephras TT-7; 8; 9 and 10 (5.9 - 2.0 cal. ka BP) contain glass shards with similar Ba/Th ratios to older and younger Tilo tephras (Fig. S5).

\section{Glass chemistry of the Lake Chamo tephras}

CHT-1 and CHT-2 glass shards can be distinguished based up their variable $\mathrm{Al}_{2} \mathrm{O}_{3}, \mathrm{Nb}$, Ba and Th concentrations (Fig. S6 b, c, e). CHT-1 (1.9 - 1.5 cal. ka BP) glass shards contain higher $\mathrm{Al}_{2} \mathrm{O}_{3}$ and $\mathrm{Ba}$ concentrations and lower $\mathrm{Zr}$, Nb and Th concentrations than CHT-2 (8.3 - $7.8 \mathrm{cal} \mathrm{ka} \mathrm{BP,} \mathrm{Fig.} \mathrm{S6} \mathrm{b,} \mathrm{c,} \mathrm{e,} \mathrm{f).} \mathrm{Both} \mathrm{Chamo} \mathrm{tephras} \mathrm{have} \mathrm{identical} \mathrm{Zr/Th} \mathrm{ratios,} \mathrm{indicating} \mathrm{they} \mathrm{are} \mathrm{derived} \mathrm{from} \mathrm{a}$ shared volcanic source (Fig. S6 f)

\section{Glass chemistry of the Lake Awassa tephras}

The Awassa tephra glass shards share similar Zr/Th ratios (Fig. S7), suggesting that they are co-genetic. However, FeOT, Y, Zr, La, $\mathrm{Nb}$ and Th concentrations display inter-eruptive variation, dividing Awassa tephras into three glass populations . Glass shards in AWT1 (1.5 - 1.3 cal. ka BP) typically contain lower concentrations of incompatible elements than older Awassa tephras (Fig. S7 d, f). Glass shards in AWT-2 (3.8 - 3.4 cal. ka BP) and AWT-4 (6.2 - 5.7 cal. ka BP) are compositionally similar, however, AWT-2 contains higher Y concentrations than all other Awassa tephras and lower concentrations of Zr and Th than AWT-2 (Fig. S5 d, f). 
Table DR4 Normalised major element (wt.\%) and trace element concentrations in glass shards in the Tilo tephras TT-1 to TT-7.

Average ( \pm 1 st. dev.) concentrations of selected trace elements which have proved useful for discrimination and correlation are shown here, and the minimum and maximum element concentrations of each tephra are given in italics. For analytical considerations, see the Supplementary Excel file. The full glass composition dataset is available from the author upon request.

\begin{tabular}{|c|c|c|c|c|c|c|c|}
\hline & TT-1 & TT-2 & TT-3 & TT-4 & TT-5 & TT-6 & TT-7 \\
\hline Age (ka) & $1.3-0.5$ & $1.5-1.3$ & $1.8-1.3$ & $2.4-1.4$ & $2.5-1.7$ & $2.7-2.2$ & $3.1-2.0$ \\
\hline Thickness (cm) & 4.5 & 20 & 0.5 & 2 & 5 & 1 & 1 \\
\hline $\mathrm{Zr} / \mathrm{Th}$ & $74.4-89.5$ & $72.8-85.1$ & $55.9-62.9$ & $70.5-80.7$ & $72.7-87.1$ & $56.2-65.2$ & $73.4-92.1$ \\
\hline $\mathrm{Zr} / \mathrm{La}$ & $8.80-9.32$ & $8.45-9.88$ & $7.99-8.69$ & $8.80-9.55$ & $8.71-9.99$ & $7.89-8.48$ & $9.01-9.75$ \\
\hline \multirow[t]{2}{*}{$\mathrm{SiO}_{2}$} & $74.91(0.55)$ & $74.94(0.56)$ & $73.38(0.38)$ & $74.80(0.24)$ & $74.84(0.46)$ & $73.35(0.69)$ & $74.84(0.23)$ \\
\hline & $72.99-75.41$ & $72.95-75.84$ & 72.39-73.97 & $74.35-75.31$ & 73.69-76.66 & $72.24-75.00$ & $74.41-75.22$ \\
\hline \multirow[t]{2}{*}{$\mathrm{Al}_{2} \mathrm{O}_{3}$} & $10.08(0.75)$ & $9.92(0.66)$ & $8.57(0.33)$ & $9.87(0.14)$ & $9.92(0.27)$ & $8.57(0.52)$ & $9.83(0.12)$ \\
\hline & $9.56-12.81$ & $9.39-12.51$ & $8.16-9.46$ & $9.71-10.24$ & $9.65-11.26$ & $7.47-10.07$ & $9.70-10.16$ \\
\hline \multirow[t]{2}{*}{$\mathrm{FeO}^{\mathrm{T}}$} & $4.57(0.11)$ & $4.56(0.15)$ & $6.39(0.25)$ & $4.60(0.12)$ & $4.64(0.14)$ & $6.45(0.26)$ & $4.66(0.13)$ \\
\hline & $4.38-4.75$ & $4.24-4.87$ & $5.59-6.79$ & $4.39-4.81$ & 4.36-4.97 & $5.79-6.89$ & $4.43-4.88$ \\
\hline \multirow[t]{2}{*}{$\mathrm{Na}_{2} \mathrm{O}$} & $5.31(0.17)$ & $5.45(0.19)$ & $6.38(0.30)$ & $5.38(0.17)$ & $5.28(0.39)$ & $6.45(0.19)$ & $5.39(0.13)$ \\
\hline & 4.99-5.58 & $4.76-5.79$ & $5.79-6.84$ & $5.06-5.76$ & $3.56-5.70$ & $6.12-6.84$ & $5.20-5.59$ \\
\hline \multirow[t]{2}{*}{$\mathrm{K}_{2} \mathrm{O}$} & $4.48(0.13)$ & $4.47(0.10)$ & $4.31(0.11)$ & $4.48(0.14)$ & $4.46(0.08)$ & $4.16(0.17)$ & $4.43(0.08)$ \\
\hline & $4.16-4.68$ & $4.27-4.66$ & 4.09-4.47 & $4.21-4.61$ & $4.28-4.63$ & $3.76-4.42$ & 4.31-4.61 \\
\hline \multirow[t]{2}{*}{$\mathrm{Y}$} & $260(18.4)$ & $259(34.2)$ & $265(45.3)$ & $265(14.7)$ & $280(44.2)$ & $231(17.5)$ & $230(16.4)$ \\
\hline & $236-311$ & $199-346$ & $213-377$ & $246-296$ & 212-395 & $204-274$ & $205-268$ \\
\hline \multirow[t]{2}{*}{$\mathrm{Zr}$} & $2110(131)$ & $2130(267)$ & $2090(369)$ & $2110(121)$ & $2290(348)$ & $1820(113)$ & $1880(118)$ \\
\hline & $1930-2410$ & $1630-2720$ & $1740-3090$ & $1960-2340$ & $1770-3190$ & $1640-2090$ & $1730-2130$ \\
\hline \multirow[t]{2}{*}{$\mathrm{Nb}$} & $259(8.56)$ & $262(10.7)$ & $286(36.7)$ & $269(8.07)$ & $267(18.4)$ & $274(15.4)$ & $245(6.64)$ \\
\hline & $243-276$ & $222-279$ & $239-356$ & $254-286$ & $233-337$ & 233-301 & $233-260$ \\
\hline \multirow[t]{2}{*}{$\mathrm{Ba}$} & $94.4(5.74)$ & $92.1(10.0)$ & 438 (29.4) & $83.3(6.95)$ & $82.5(9.29)$ & $358(22.8)$ & $57.6(4.74)$ \\
\hline & $81.7-107$ & $71.7-111$ & $394-517$ & $70.5-94.1$ & 56.1-102 & $312-414$ & $51.5-71.9$ \\
\hline \multirow[t]{2}{*}{$\mathrm{La}$} & $234(12.5)$ & $234(24.7)$ & $250(44.5)$ & $232(14.0)$ & $245(33.3)$ & $224(16.6)$ & $201(13.8)$ \\
\hline & $215-259$ & 193-292 & 204-363 & $214-259$ & $191-323$ & $198-263$ & $181-226$ \\
\hline \multirow[t]{2}{*}{$\mathrm{Hf}$} & $52.5(4.02)$ & $53.5(6.05)$ & $53.1(8.53)$ & $56.4(4.44)$ & $58.0(8.98)$ & $45.4(3.46)$ & $46.7(3.18)$ \\
\hline & $47.7-63.0$ & $44.2-65.3$ & $44.6-75.1$ & $50.6-65.0$ & $45.4-80.3$ & $38.6-53.7$ & 41.1-52.1 \\
\hline \multirow[t]{2}{*}{ Th } & $26.4(1.71)$ & $26.9(3.39)$ & $35.2(6.60)$ & $28.1(2.21)$ & $28.4(4.08)$ & $30.1(2.52)$ & $23.1(1.63)$ \\
\hline & $24.3-29.7$ & $21.8-33.4$ & $28.0-52.8$ & $25.1-32.0$ & $22.6-40.3$ & $25.1-37.1$ & $21.1-26.4$ \\
\hline \multirow[t]{3}{*}{$\mathrm{U}$} & $6.32(0.37)$ & $6.66(0.857)$ & $7.61(0.924)$ & $7.42(0.445)$ & $7.31(0.583)$ & $7.37(0.583)$ & $6.58(0.239)$ \\
\hline & $5.80-7.29$ & $4.18-8.60$ & $6.15-9.40$ & $6.78-8.26$ & 5.84-8.16 & 6.44-8.35 & 5.98-6.92 \\
\hline & $\mathrm{n}=16$ & $\mathrm{n}=48$ & $\mathrm{n}=18$ & $\mathrm{n}=19$ & $\mathrm{n}=40$ & $\mathrm{n}=23$ & $\mathrm{n}=19$ \\
\hline
\end{tabular}


Table DR5 Normalised major element (wt.\%) and trace element concentrations in glass shards in the Tilo tephras TT-7 to TT-14. Average ( \pm 1 st. dev.) concentrations of selected trace elements which have proved useful for discrimination and correlation are shown here, and the minimum and maximum element concentrations of each tephra are given in italics. For analytical considerations, see the Supplementary Excel file. The full glass composition dataset is available from the author upon request.

\begin{tabular}{|c|c|c|c|c|c|c|c|}
\hline & TT-8 & TT-9 & TT-10 & TT-11 & TT-12 & TT-13 & TT-14 \\
\hline Age (ka) & $3.3-2.0$ & $4.8-4.5$ & $5.9-4.9$ & $6.4-5.8$ & $6.7-6.3$ & $8.7-8.3$ & $10.1-9.8$ \\
\hline Thickness (cm) & 37 & 38 & 30 & 6 & 35 & 5 & 48 \\
\hline $\mathrm{Zr} / \mathrm{Th}$ & $69.1-87.4$ & $73.0-86.4$ & $71.6-87.3$ & $69.64-85.5$ & $65.1-78.2$ & $75.8-88.2$ & $71.2-87.3$ \\
\hline $\mathrm{Zr} / \mathrm{La}$ & $8.48-9.89$ & $8.42-9.38$ & $8.30-9.70$ & $8.61-9.51$ & $7.98-8.92$ & $9.10-9.64$ & $8.83-9.79$ \\
\hline \multirow[t]{2}{*}{$\mathrm{SiO}_{2}$} & $74.97(0.52)$ & $75.18(0.52)$ & $75.14(0.49)$ & $75.12(1.01)$ & $74.82(0.90)$ & $74.73(2.14)$ & $75.07(1.23)$ \\
\hline & $73.82-76.91$ & $74.36-75.65$ & 74.58-78.39 & $70.25-77.13$ & $71.02-78.00$ & 66.63-78.05 & $67.28-76.58$ \\
\hline $\mathrm{Al}_{2} \mathrm{O}_{3}$ & $9.41-11.28$ & $9.40-10.06$ & $8.57-10.26$ & $9.25-14.67$ & $9.43-14.63$ & $9.16-18.28$ & $8.99-17.76$ \\
\hline \multirow[t]{2}{*}{$\mathrm{FeO}^{\mathrm{T}}$} & $4.67(0.21)$ & $4.68(0.21)$ & $4.64(0.20)$ & $4.62(0.36)$ & $4.70(0.16)$ & $4.65(0.91)$ & $4.58(0.57)$ \\
\hline & $4.33-5.78$ & $4.33-5.02$ & $3.76-5.02$ & $2.72-5.04$ & $4.29-5.05$ & $0.94-5.06$ & $0.66-4.84$ \\
\hline $\mathrm{Na}_{2} \mathrm{O}$ & $5.22(0.53)$ & $5.36(0.53)$ & $5.43(0.24)$ & $5.15(0.69)$ & $5.23(0.75)$ & $5.51(0.98)$ & $5.49(0.34)$ \\
\hline \multirow[t]{2}{*}{ Y } & $264(23.7)$ & $256(23.7)$ & 267 (32.9) & $310(32.9)$ & $305(30.4)$ & $356(27.8)$ & $291(20.8)$ \\
\hline & $218-321$ & $216-298$ & $209-347$ & $223-369$ & $238-394$ & $300-432$ & $239-345$ \\
\hline \multirow[t]{2}{*}{$\mathrm{Zr}$} & $2120(184)$ & $2100(184)$ & $2190(248)$ & $2440(238)$ & $2300(229)$ & 2960 (212) & $2410(164)$ \\
\hline & $1750-2500$ & $1740-2400$ & $1770-2780$ & $1790-2850$ & $1790-2800$ & $2460-3460$ & $2030-2750$ \\
\hline \multirow[t]{2}{*}{$\mathrm{Nb}$} & $265(17.1)$ & $272(17.1)$ & $276(13.4)$ & $293(28.3)$ & $296(19.1)$ & 335 (13.9) & $303(14.0)$ \\
\hline & $211-311$ & $247-289$ & $227-297$ & $212-330$ & $255-330$ & $313-361$ & 264-335 \\
\hline \multirow[t]{2}{*}{$\mathrm{Ba}$} & $71.4(8.48)$ & $64.2(8.48)$ & $67.3(7.60)$ & $55.9(13.0)$ & $49.2(6.33)$ & $55.0(6.63)$ & $56.4(6.05)$ \\
\hline & $59.0-96.68$ & $51.8-78.8$ & $56.4-88.0$ & $35.2-96.2$ & $35.5-65.8$ & $44.6-70.1$ & $46.4-74.1$ \\
\hline \multirow[t]{2}{*}{$\mathrm{La}$} & $234(23.4)$ & $233(23.4)$ & $243(30.1)$ & $268(24.7)$ & $268(24.3)$ & 315 (22.9) & $259(17.8)$ \\
\hline & $191-293$ & $198-266$ & $190-311$ & $205-310$ & $206-323$ & $264-367$ & $212-302$ \\
\hline $\mathrm{U}$ & $\mathrm{n}=57$ & $\mathrm{n}=59$ & $\mathrm{n}=61$ & $\mathrm{n}=39$ & $\mathrm{n}=58$ & $\mathrm{n}=19$ & $\mathrm{n}=52$ \\
\hline
\end{tabular}



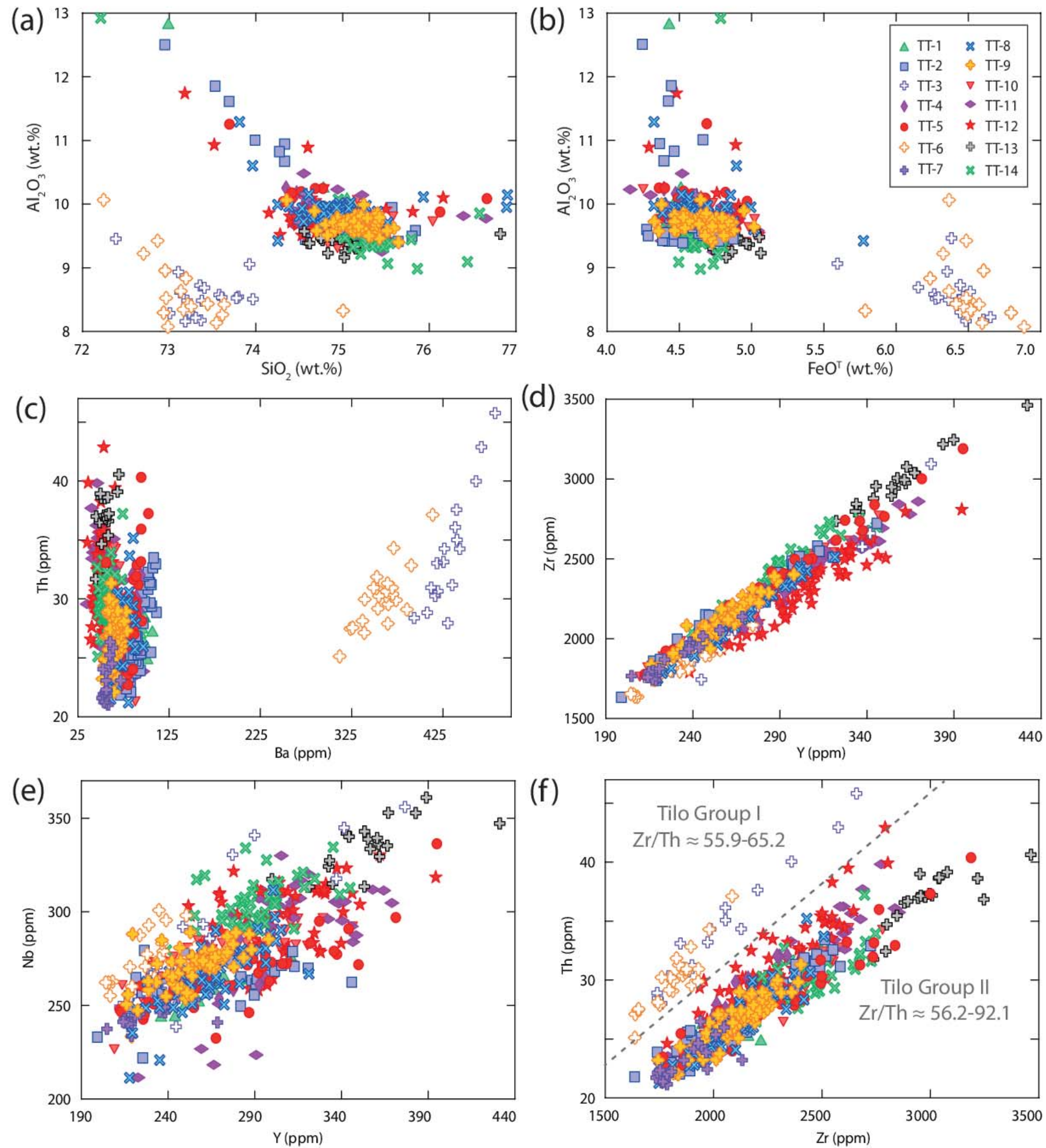

Fig. DR5 Bi-plots of selected major and trace element concentrations in the Tilo tephra glass shards. (f) Glass shards in TT-3 and TT-6 have distinct $\mathrm{Zr} / \mathrm{Th}$ ratios, indicating they are derived from a distinct volcanic source. All other Tilo tephras have a co-genetic origin. 
Table DR6 Normalised major element (wt.\%) and trace element concentrations in glass shards in the Chamo tephras CHT-1 and CHT-2. Average ( \pm 1 st. dev.) concentrations of selected trace elements which have proved useful for discrimination and correlation are shown here, and the minimum and maximum element concentrations of each tephra are given in italics. For analytical considerations, see the Supplementary Excel file. The full glass composition dataset is available from the author upon request.

CHT-1 CHT-2

\begin{tabular}{lll}
\hline Age (ka) & $2.3-1.5$ & $8.9-7.7$ \\
Thickness (cm) & $<1$ & 1 \\
$\mathrm{Zr} / \mathrm{Th}$ & $73.9-86.7$ & $73.1-84.9$ \\
$\mathrm{Zr} / \mathrm{La}$ & $8.07-9.27$ & $8.63-9.90$ \\
\hline $\mathrm{SiO}_{2}$ & $75.04(0.26)$ & $74.86(0.43)$ \\
& $74.65-75.72$ & $74.33-76.37$ \\
$\mathrm{Al}_{2} \mathrm{O}_{3}$ & $9.74(0.12)$ & $9.44(0.12)$ \\
& $9.50-10.01$ & $9.19-9.61$ \\
$\mathrm{FeO}^{\mathrm{T}}$ & $4.63(0.17)$ & $4.90(0.14)$ \\
& $4.32-4.86$ & $4.56-5.18$ \\
$\mathrm{Na}_{2} \mathrm{O}$ & $5.29(0.16)$ & $5.61(0.41)$ \\
& $4.87-5.50$ & $4.06-6.07$ \\
$\mathrm{~K}_{2} \mathrm{O}$ & $4.42(0.12)$ & $4.33(0.08)$ \\
& $4.10-4.56$ & $4.20-4.47$ \\
$\mathrm{Y}$ & $302(34.6)$ & $332(38.2)$ \\
& $262-366$ & $283-452$ \\
$\mathrm{Zr}$ & $2420(235)$ & $2700(324)$ \\
& $2150-2790$ & $2360-3760$ \\
$\mathrm{Nb}$ & $276(16.3)$ & $333(13.6)$ \\
& $250-320$ & $304-371$ \\
$\mathrm{Ba}$ & $108(12.5)$ & $50.6(8.93)$ \\
& $68.4-121$ & $42.7-73.2$ \\
$\mathrm{La}$ & $283(26.7)$ & $288(43.3)$ \\
& $246-335$ & $254-436$ \\
$\mathrm{Hf}$ & $57.4(5.55)$ & $65.7(8.10)$ \\
& $47.2-66.4$ & $57.7-94.9$ \\
$\mathrm{Th}$ & $29.3(2.74)$ & $33.9(3.74)$ \\
& $25.8-33.7$ & $30.2-47.2$ \\
$\mathrm{U}$ & $6.82(0.529)$ & $9.06(0.499)$ \\
& $5.71-7.54$ & $7.68-9.93$ \\
\hline & $\mathrm{n}=16$ & $\mathrm{n}=19$ \\
& &
\end{tabular}


(a)

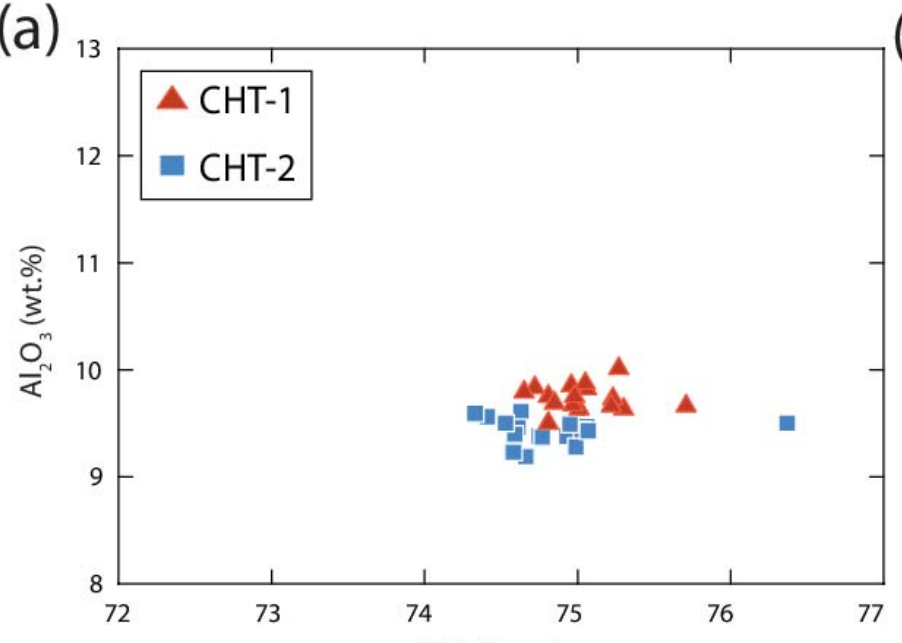

(c)
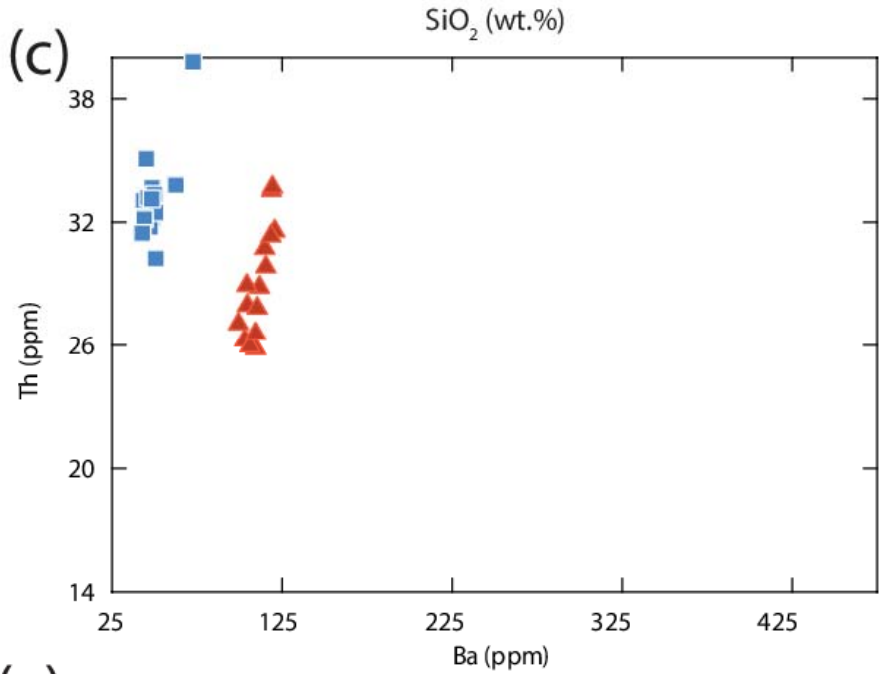

(e)

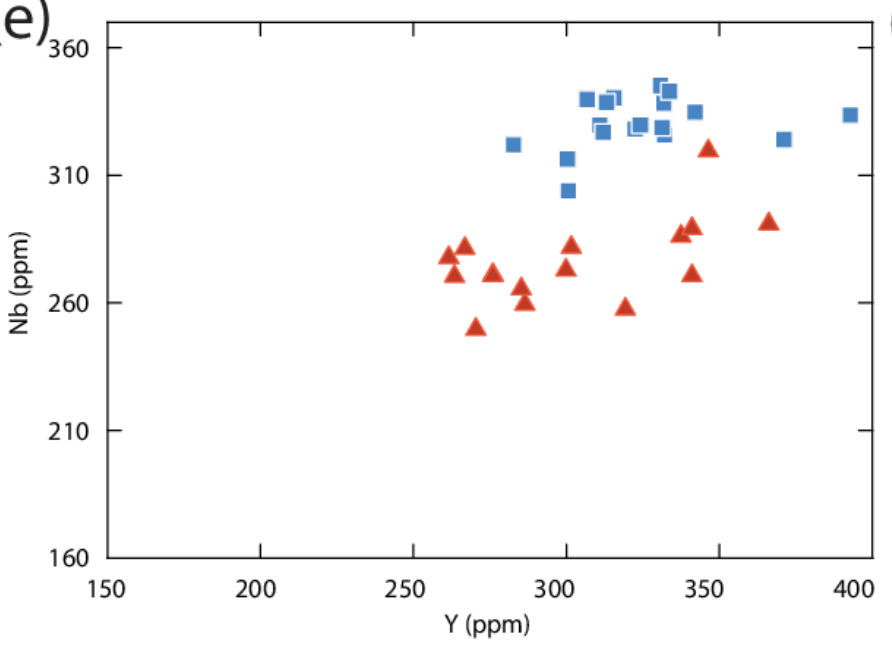

(b)

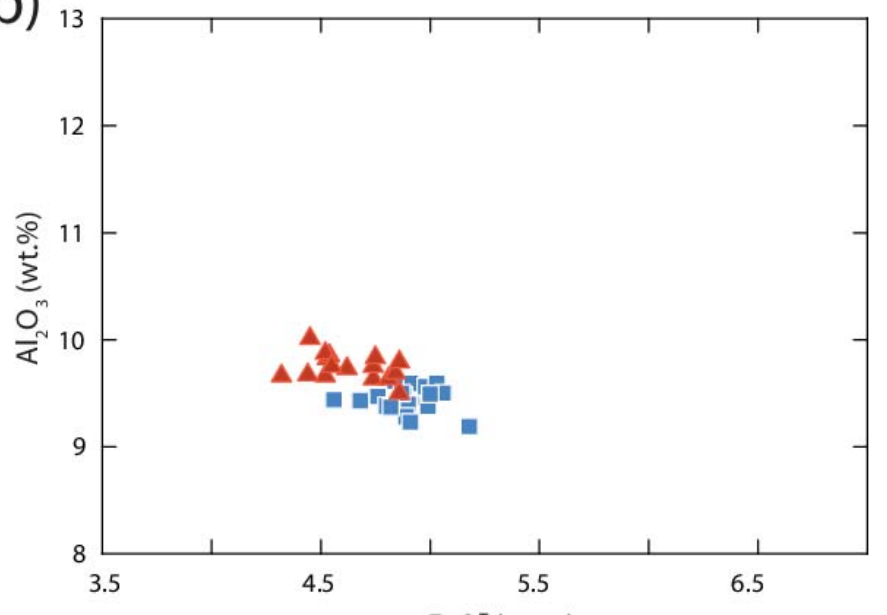

(d)

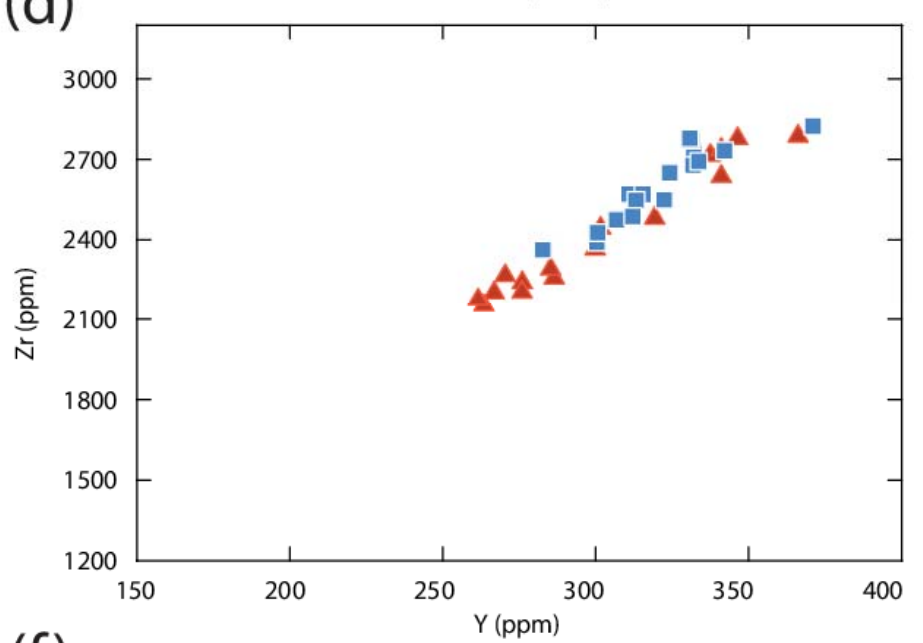

(f)

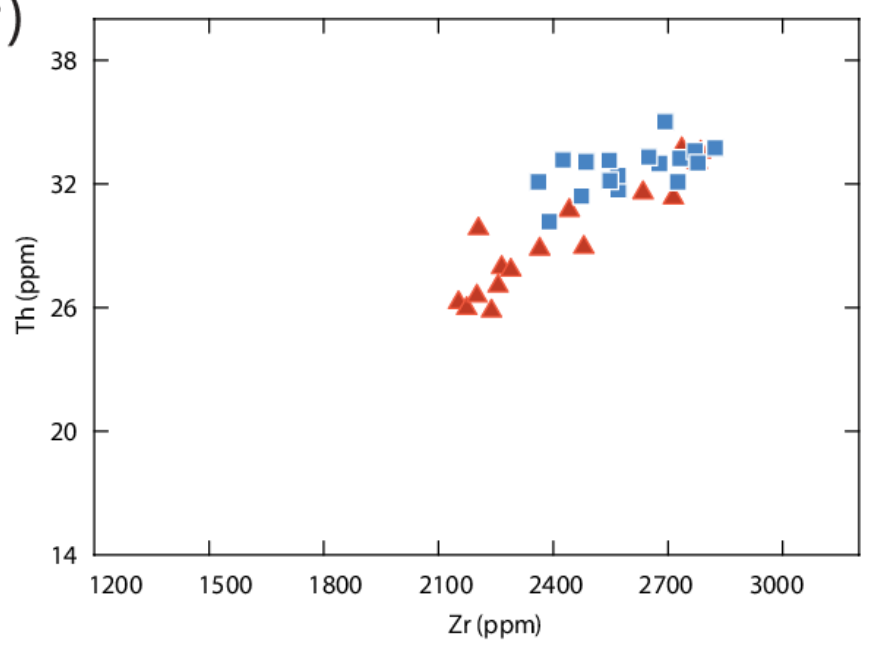

Fig. DR6 Bi-plots of selected major and trace element concentrations in the Chamo tephra glass shards. Glass in CHT-1 and CHT-2 share identical incompatible element ratios, suggesting they are derived from a shared volcanic source. 
Table DR7 Normalised major element (wt.\%) and trace element concentrations in glass shards in the Awassa tephras, only AWT-1, AWT-2 and AWT-4 were analysed in this study. Average ( \pm 1 st. dev.) concentrations of selected trace elements which have proved useful for discrimination and correlation are shown here, and the minimum and maximum element concentrations of each tephra are given in italics. For analytical considerations, see the Supplementary Excel file. The full glass composition dataset is available from the author upon request.

\begin{tabular}{llll} 
& AWT-1 & AWT-2 & AWT-4 \\
\hline Age (ka) & $1.5-1.3$ & $3.8-3.4$ & $6.2-5.7$ \\
$\mathrm{Thickness} \mathrm{(cm)}$ & 14 & 4 & 73 \\
$\mathrm{Zr} / \mathrm{Th}$ & $49.6-83.7$ & $66.9-85.4$ & $72.8-82.1$ \\
$\mathrm{Zr} / \mathrm{La}$ & $6.63-8.65$ & $6.83-8.90$ & $8.70-9.21$ \\
\hline $\mathrm{SiO}_{2}$ & $74.08(2.49)$ & $75.42(0.27)$ & $74.93(0.34)$ \\
& $66.81-75.80$ & $75.09-76.09$ & $74.33-75.37$ \\
$\mathrm{Al}_{2} \mathrm{O}_{3}$ & $11.12(2.54)$ & $9.62(0.14)$ & $9.65(0.13)$ \\
& $9.35-19.13$ & $9.37-9.92$ & $9.43-9.88$ \\
$\mathrm{FeO}$ & $4.06(1.39)$ & $4.60(0.12)$ & $4.78(0.23)$ \\
& $0.52-6.43$ & $4.41-4.89$ & $4.53-5.36$ \\
$\mathrm{Na}{ }_{2} \mathrm{O}$ & $5.03(0.68)$ & $5.20(0.27)$ & $5.23(0.15)$ \\
& $3.44-6.17$ & $4.58-5.59$ & $4.97-5.51$ \\
$\mathrm{~K}_{2} \mathrm{O}$ & $5.08(0.98)$ & $4.47(0.11)$ & $4.43(0.14)$ \\
& $4.26-7.36$ & $4.34-4.71$ & $4.18-4.55$ \\
$\mathrm{Y}$ & $203(28.7)$ & $285(34.0)$ & $294(26.5)$ \\
& $126-237$ & $227-357$ & $256-339$ \\
$\mathrm{Zr}$ & $1620(236)$ & $2030(254)$ & $2400(228)$ \\
& $1060-1910$ & $1610-2470$ & $2130-2830$ \\
$\mathrm{Nb}$ & $213(27.2)$ & $260(19.0)$ & $278(16.0)$ \\
& $171-260$ & $221-287$ & $246-305$ \\
$\mathrm{Ba}$ & $237(130)$ & $81.2(33.0)$ & $69.8(9.74)$ \\
& $29.7-481$ & $62.7-196$ & $60.1-94.1$ \\
$\mathrm{La}$ & $210(21.3)$ & $251(25.3)$ & $269(27.1)$ \\
$\mathrm{Hf}$ & $153-238$ & $211-299$ & $235-316$ \\
$\mathrm{Th}$ & $44.1(4.94)$ & $51.8(5.61)$ & $63.6(5.56)$ \\
$\mathrm{U}$ & $31.5-52.9$ & $43.9-62.61$ & $56.6-72.3$ \\
& $22.8(3.69)$ & $26.5(3.18)$ & $31.4(3.46)$ \\
& $16.9-31.1$ & $22.2-33.0$ & $26.6-38.8$ \\
& $6.43(1.15)$ & $7.54(1.82)$ & $8.11(0.71)$ \\
& $5.01-8.98$ & $5.23-13.3$ & $7.09-9.11$ \\
\hline & & $\mathrm{n}=28$ & $\mathrm{n}=10$ \\
& & &
\end{tabular}



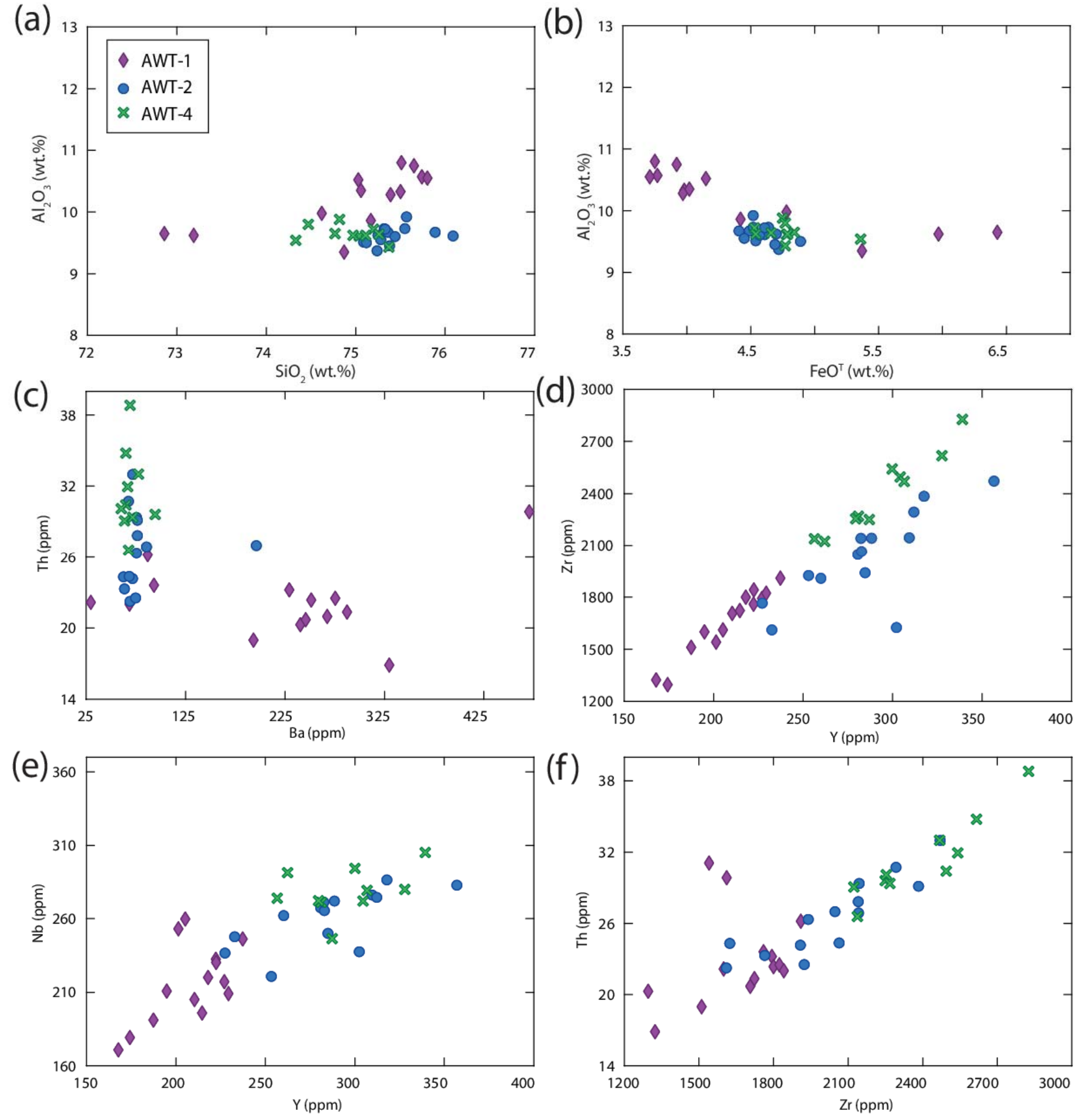

Fig. DR7 Bi-plots of selected major and trace element concentrations in the Awassa tephra glass shards. Glass shards in AWT-1, AWT-2 and AWT-4 have similar incompatible element ratios, implying a co-gentic origin. (c) AWT-1 is distinct in having bimodal glass composition. 


\section{S2 c Tephra correlations}

AWT-2 and AWT-4 tephras have similar elemental compositions and $\mathrm{Zr} / \mathrm{Th}$ ratios to the low $\mathrm{FeO}^{\mathrm{T}}$ Tilo tephras, suggesting that some Awassa and Tilo tephras are derived from a shared source (Fig. S8). Glass shards in AWT-2 and AWT-4 (6.2 - 3.4 cal. ka BP) contain similar Ba concentrations to TT-7, TT-8, TT-9 and TT-10 (5.9 - 2.0 cal. ka BP). However, it is not possible to identify definitively those tephras that were produced by the same eruptive event (Fig. S8). Although we cannot correlate these tephras to individual events, we can use their glass composition as a broad signature for the Holocene eruptive from nearby Corbetti.

Both Chamo tephras have similar $\mathrm{Zr} / \mathrm{Th}$ ratios and compositions to the low $\mathrm{FeO}^{\mathrm{T}}$ Tilo tephras, suggesting they have a co-genetic origin (Fig. S8 and S 10). However, the Chamo tephra glass shards are distinct from all Awassa tephras in terms of their Ba concentrations. Glass shards in CHT-1 have comparable compositions to TT-1; 2; 4 and TT-5 (Fig. S9). Glass shards in TT-4 and TT-5 are distinct in terms of their Ba concentrations (Fig. S9 c). Figure S10 shows that TT-1 has a statistically different composition to CHT-1. Based on their similar composition and comparable ages, we interpret that TT-2 $(1.5-1.3 \mathrm{cal}$. ka BP $)$ was produced by the same eruptive event as CHT-1 $(1.9-1.5$ cal. ka BP). Whilst co-genetic, the glass composition of the Wendo Koshe Younger Pumice is less evolved than CHT-1. This is consistent with their origin from a compositionally zoned magma chamber, with a change in wind direction during the eruption depositing less evolved compositions proximally and more evolved compositions distally.

Glass shards in CHT-2 (8.3 - 7.9 cal. ka BP) are compositionally similar to the older low $\mathrm{FeO}^{\mathrm{T}}$ Tilo tephras, TT-11; 12; 13 and TT-14 (10.1 - 5.8 cal. ka BP, Fig. S10). However, TT-12 and TT-14 are distinguished from CHT-2 on the basis of their $\mathrm{Al}_{2} \mathrm{O}_{3}, \mathrm{Y}$ and Th concentrations (Fig S10 b, c, d). Principal component analysis of the composition of the older Tilo tephras and CHT-2, demonstrates that TT-13 (8.7 - 8.3 cal. ka BP) is the correlative (Fig. S11). 

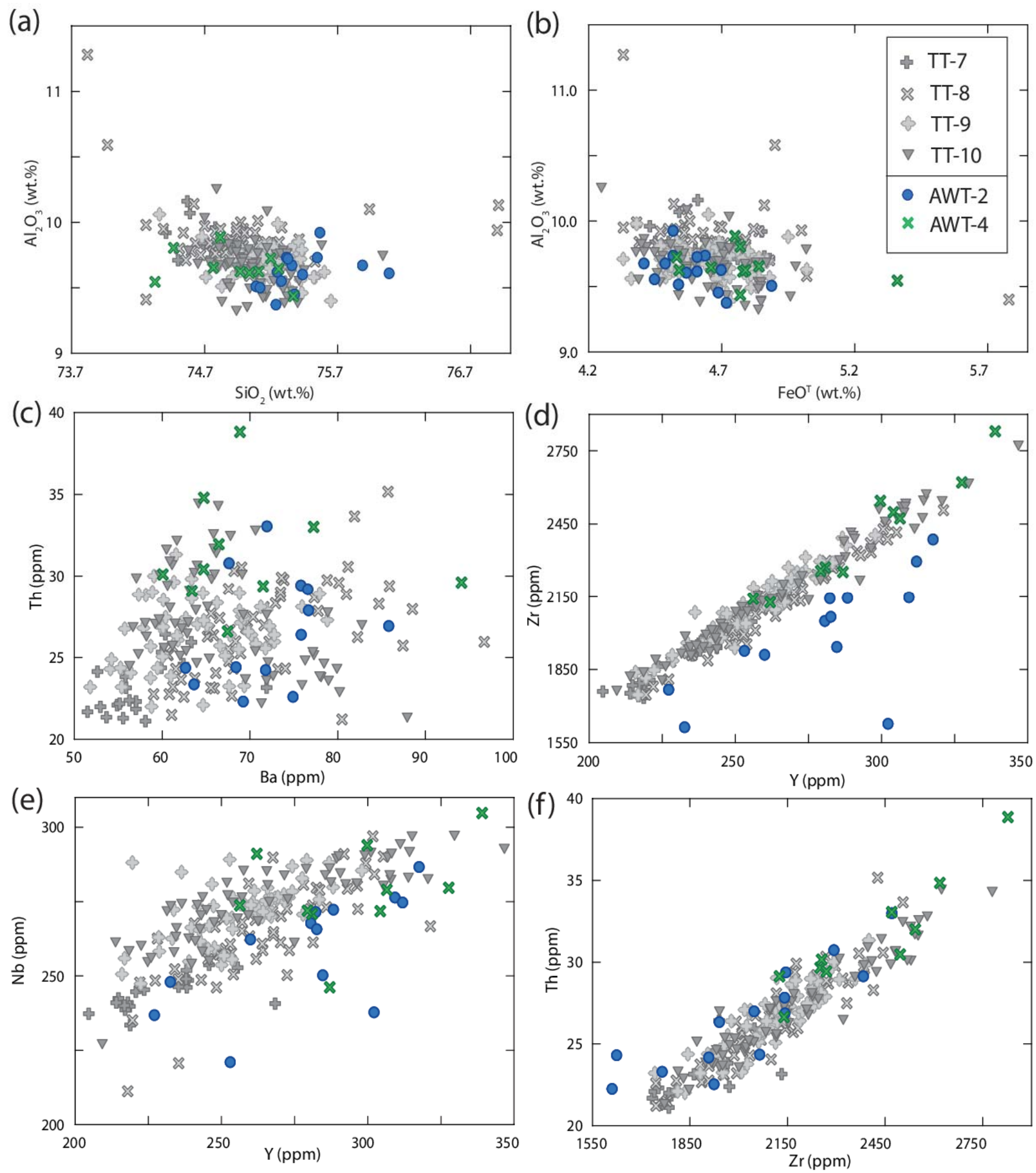

Fig. DR8 Bi-plots comparing the major and trace element composition of glass shards in selected Tilo tephras with glass shards in AWT-2 and AWT-4. The Awassa tephras cannot be correlated to individual Tilo tephras based on their major and trace element composition. 
(a) 12.2

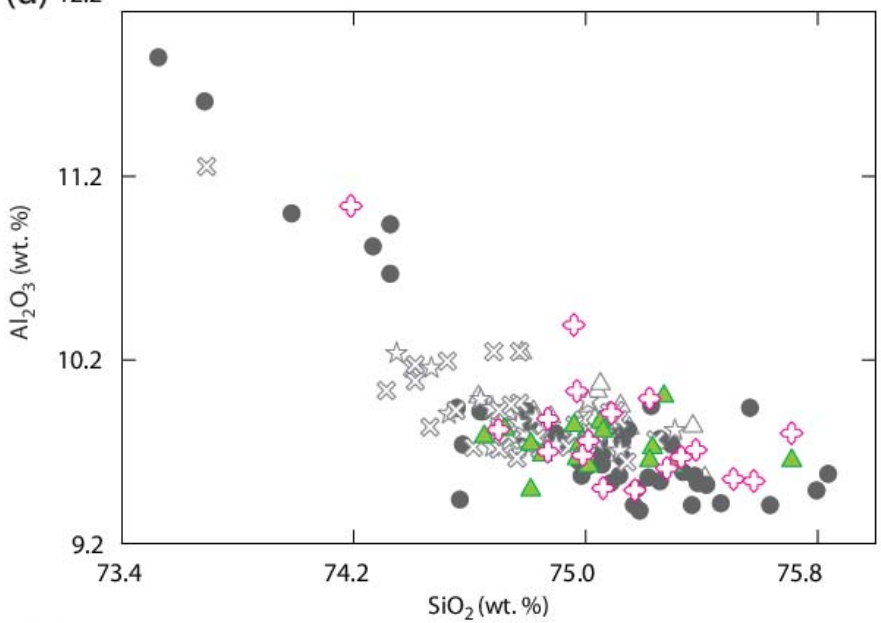

(c)
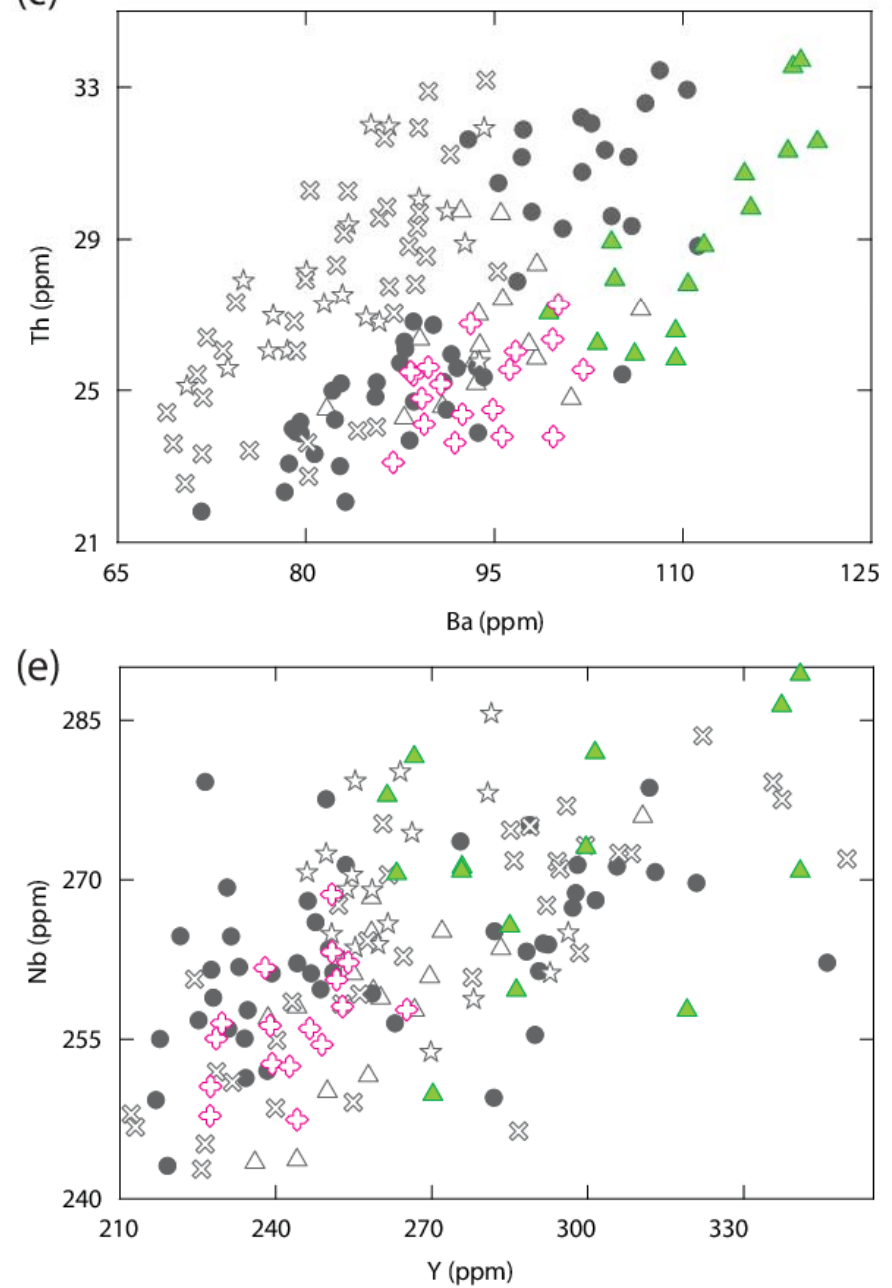

(b) 12.2

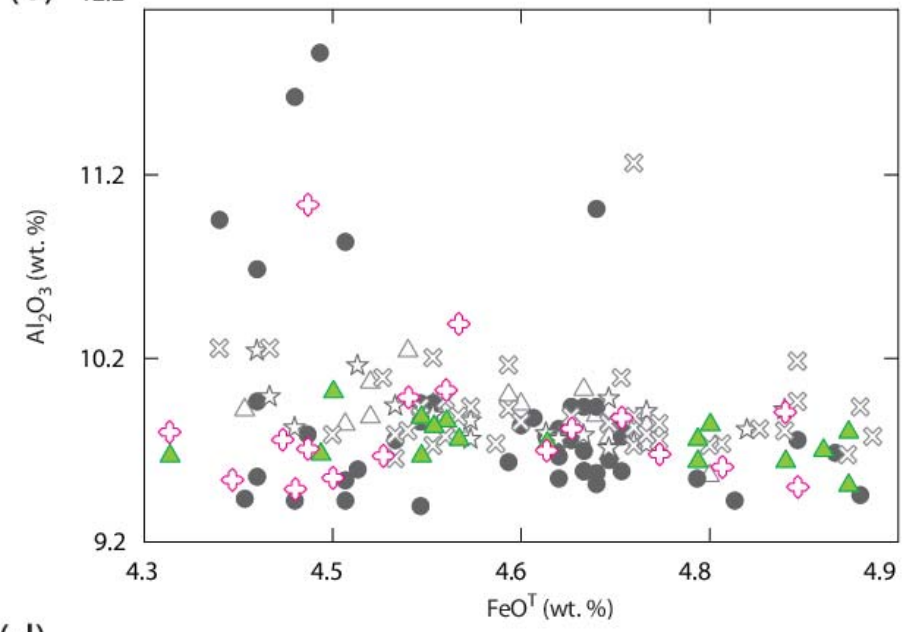

(d)

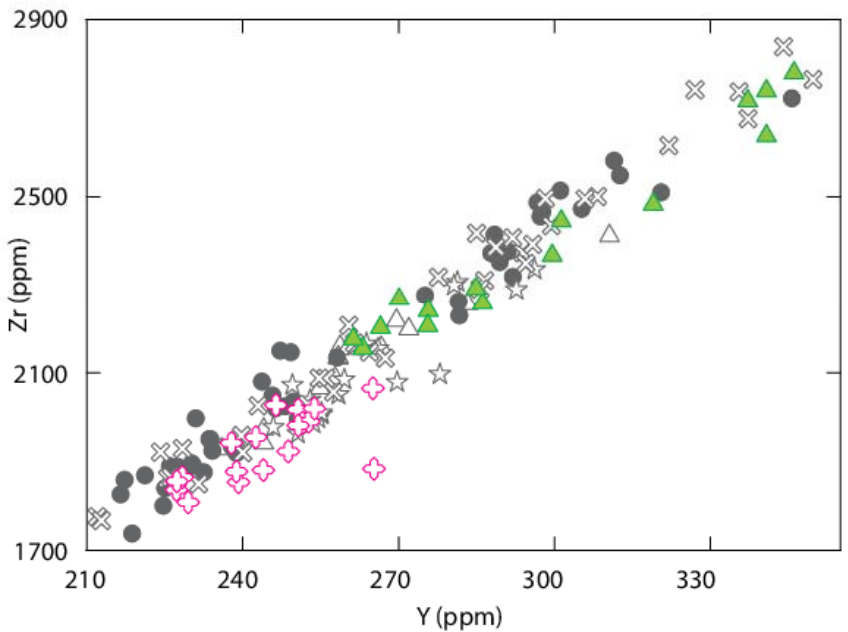

(f)

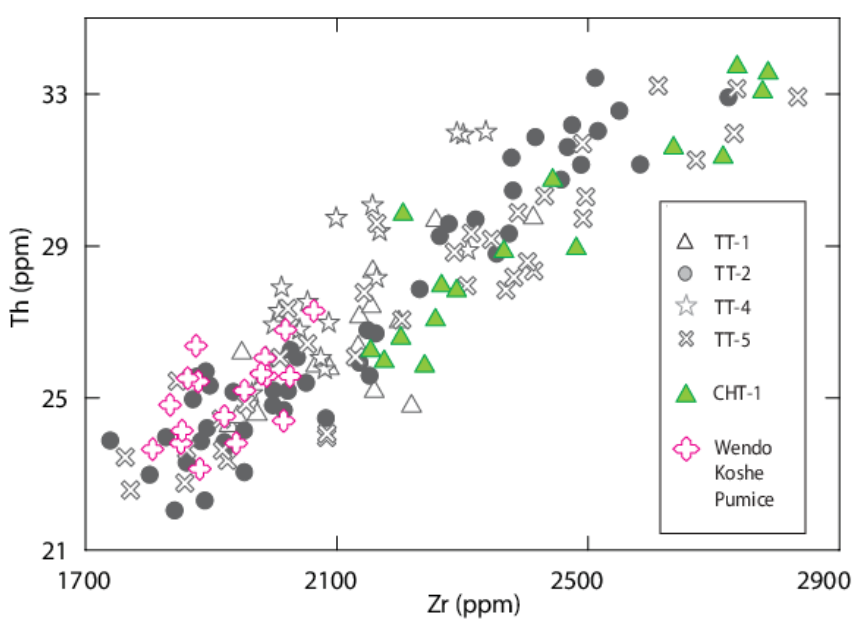

Fig. DR9 Bi-plots comparing the major and trace element composition of glass shards in younger Tilo tephras, TT-1 - TT-5, with glass shards in CHT-1 and the Wendo Koshe Pumice. CHT-1 and TT-2 glass shards occupy the same compositional fields, indicating they are correlatives. Both tephras correlate to the Wendo Koshe Pumice on the basis of their similar composition and ages. Small differences in incompatible element concentrations may be related to compositional zoning of the magma chamber, and/or differential dispersal of different eruption phases. 

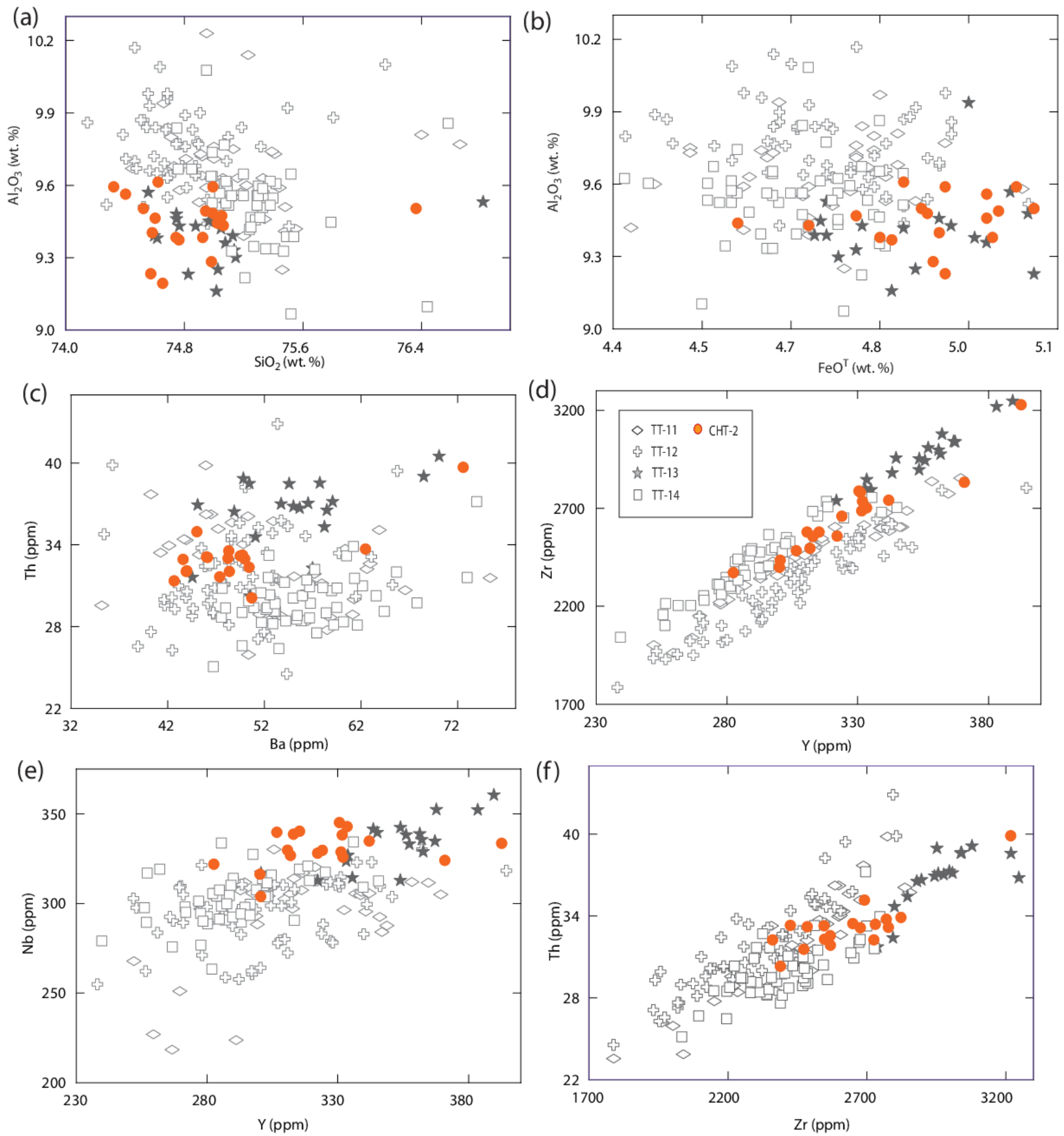

Fig. DR10 Bi-plots comparing the major and trace element composition of glass shards in older Tilo tephras, TT-11 - TT-14, with glass shards in CHT-2. Based on their similar composition and age, we correlate TT-13 and CHT-2. 
(a)

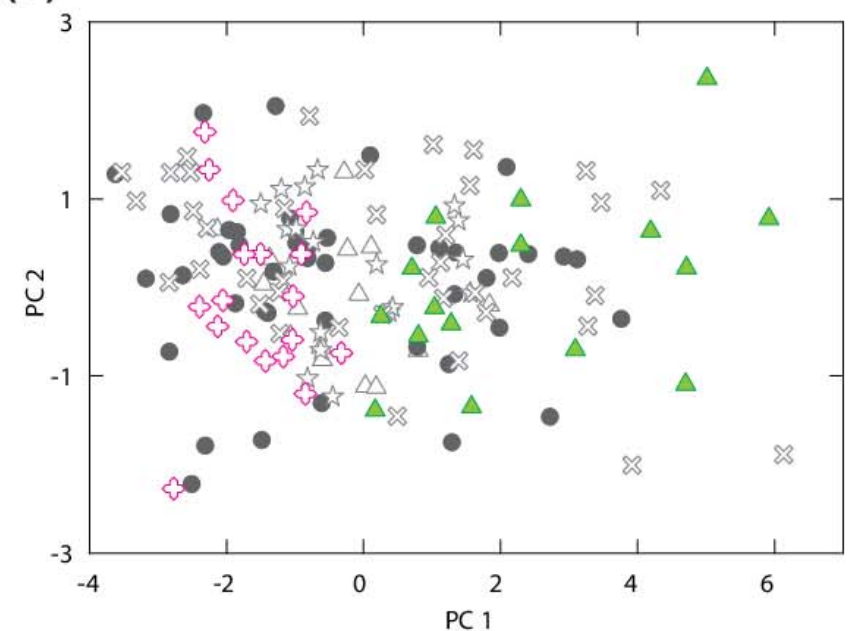

(b)

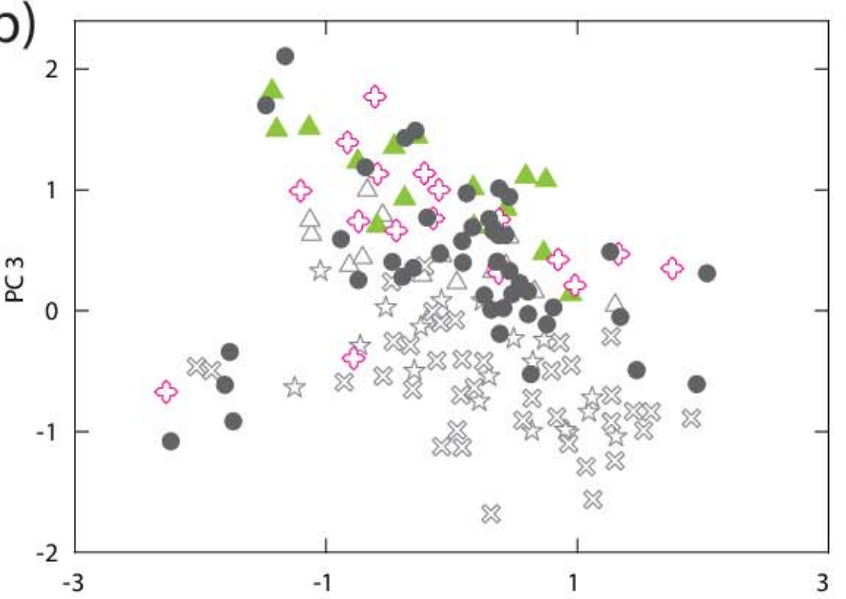

(c)

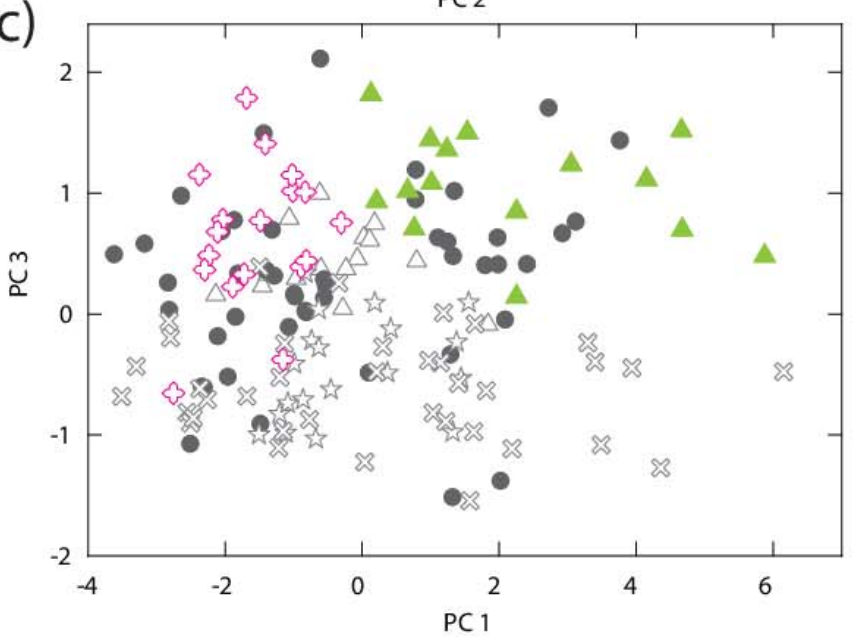

(d)

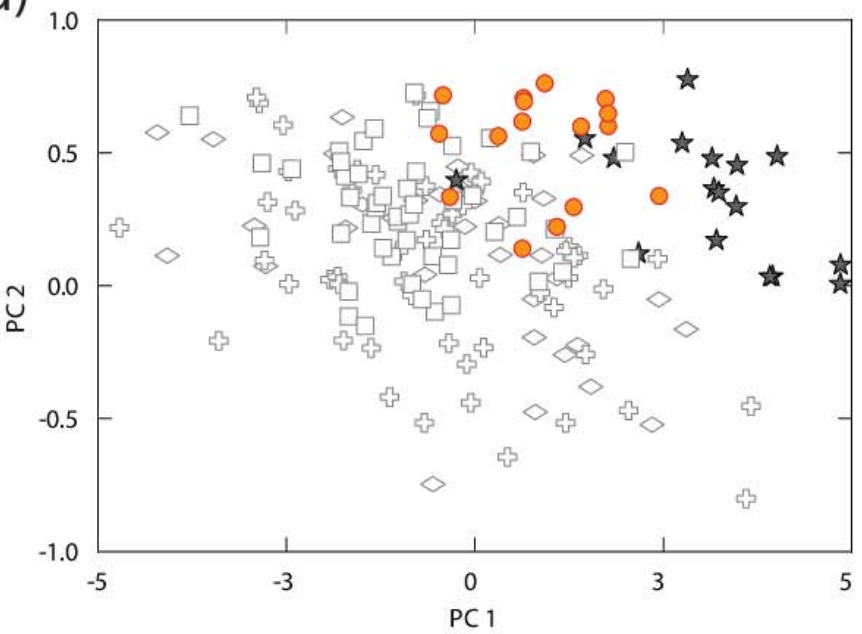

(e)

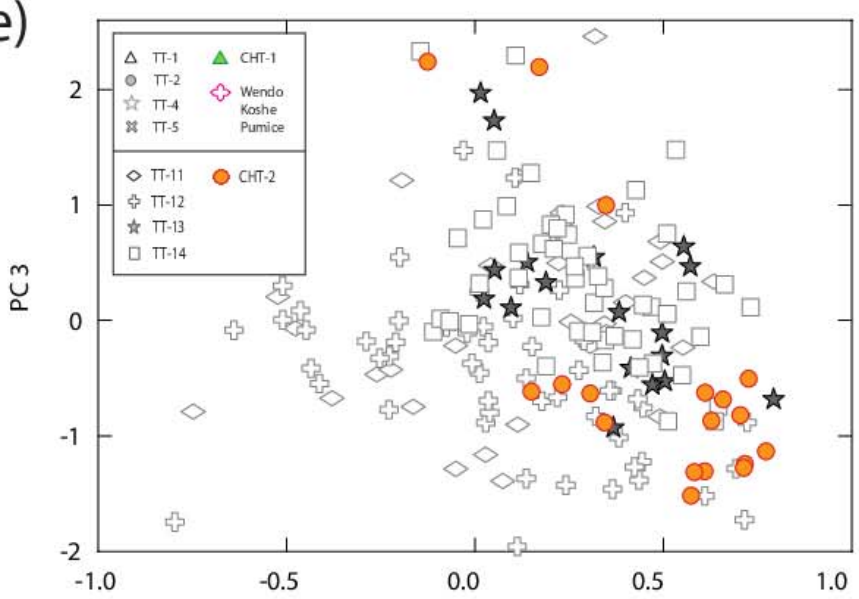

(f)

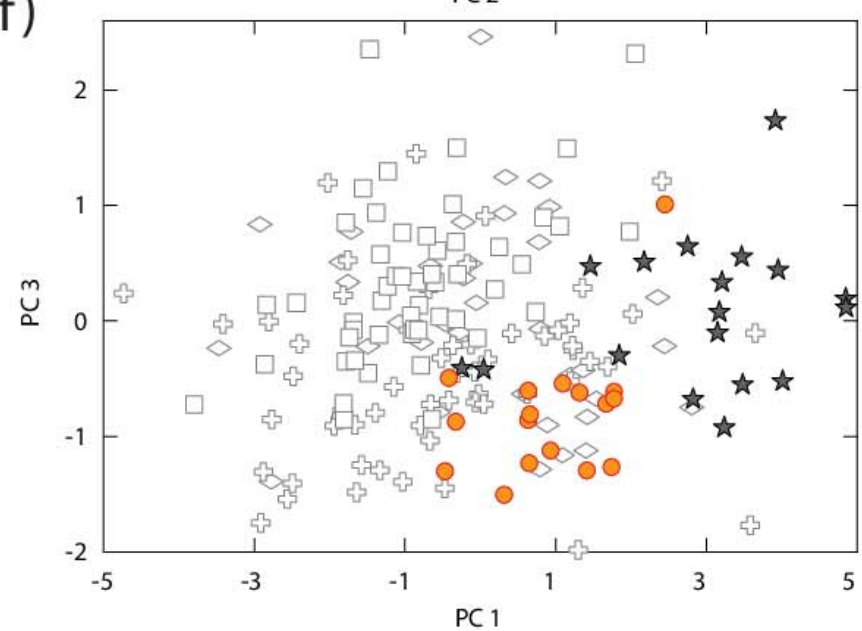

Fig. DR11 Principal components plots of the composition of glass shards in selected Tilo tephras with those in the Chamo tephras. Bi-plots show the first three principal components plotted against each other. (c) We correlated TT-2, CHT-1 and the Wendo Koshe Pumice, the remaining Tilo tephras have statistically different compositions. (b, f) TT-13 and CHT-2 have the most similar compositions, confirming our correlation. 


\section{DR2 d Tephra sources}

The major and trace element composition of the Wendo Koshe Pumice and Chabbi Obsidian (see Table DR8), sampled from inside the Corbetti caldera, are compared with the composition of tephras from lake archives in Figure 2. Published glass data for Holocene volcanoes in the MER is limited. However, published bulk compositions of post- caldera tephras from Gedemsa (Peccerillo et al., 2003) and Alutu (Hutchison et al., 2016) and obsidian melt inclusion analyses from Fentale (Taylor et al., 1997) are shown for comparison in Figure 2. These volcanoes are also listed by the World Bank at a high level of uncertainty and risk. Fentale last erupted in 1820 (Siebert et al., 2010). Whilst obsidian is erupted effusively, and does not form widespread deposits, it provides a broad glass compositional fingerprint for a given volcano. Bulk analyses contain contaminant minerals nonetheless incompatible element ratios can be used for broad comparison. Distinct major and trace element concentrations and variable incompatible element ratios of glass shards in the Tilo, Awassa and Chamo tephras indicate that three volcanic centres are responsible for generating the 19 tephra layers we have geochemically characterised.

Most Awassa, Tilo and Chamo tephras have similar compositions and $\mathrm{Zr} / \mathrm{Th}$ ratios $(\sim 65.2-99.4)$ to both the Corbetti obsidian and the Wendo Koshe Younger Pumice ( $\mathrm{Zr} / \mathrm{Th} \sim 68.9$ - 87.5, Fig 2 b). Therefore, we infer that the majority of tephras derive from centres within the Corbetti caldera. To identify the sources of TT- 3 and TT- 6 and AWT-1, further sampling and glass analyses of volcanic centres in the Main Ethiopian Rift are required. Glass shards in the Wendo Koshe Younger Pumice, sampled from inside the Corbetti Caldera, are compositionally similar to TT-2 and CHT-1 (Figs. DR9 and DR11). These tephras contain characteristically high Ba concentrations (Fig DR9 c). Whilst co-genetic, CHT-2 glass shards are more enriched in incompatible elements than the Wendo Koshe Younger Pumice (Fig. DR9 d, f). This may be associated with compositional zoning at the source volcano, with more evolved compositions only dispersed towards distal locations.

Shards in TT-3 and TT-6 have distinct elemental compositions and Zr/Th ratios when compared with the composition of the other Tilo tephras and those tephras and obsidians collected from Corbetti, Fentale, Gedemsa and Alutu (Fig. 2 b). 
Table DR8 Normalised major element (wt.\%) and trace element concentrations of glass in the Wendo Koshe Pumice (ST-NW1) and Chabbi obsidians (E950010, E950011, E950019) were analysed in this study. Average ( \pm 1 st. dev.) concentrations of selected trace elements which have proved useful for discrimination and correlation are shown here, and the minimum and maximum element concentrations of each tephra are given in italics. For analytical considerations, see the Supplementary Excel file. The full glass composition dataset is available from the author upon request.

\begin{tabular}{|c|c|c|c|c|}
\hline & ST-NW1 & E950010 & E950011 & E950019 \\
\hline Age (ka) & $<2.3 \mathrm{ka}^{3}$ & Holocene & Holocene & Holocene \\
\hline $\mathrm{Zr} / \mathrm{Th}$ & 76.9 & 79.3 & 77.4 & 77.6 \\
\hline $\mathrm{Zr} / \mathrm{La}$ & 8.95 & 8.64 & 8.53 & 8.50 \\
\hline \multirow[t]{2}{*}{$\mathrm{SiO}_{2}$} & $72.98(1.75)$ & & & \\
\hline & $67.88-74.57$ & & & \\
\hline \multirow[t]{2}{*}{$\mathrm{Al}_{2} \mathrm{O}_{3}$} & $9.56(0.35)$ & & & \\
\hline & $8.92-10.58$ & & & \\
\hline \multirow[t]{2}{*}{$\mathrm{FeO}^{\mathrm{T}}$} & $4.42(0.17)$ & & & \\
\hline & $4.19-4.66$ & & & \\
\hline \multirow[t]{2}{*}{$\mathrm{Na}_{2} \mathrm{O}$} & $5.21(0.22)$ & & & \\
\hline & $4.69-5.57$ & & & \\
\hline \multirow[t]{2}{*}{$\mathrm{K}_{2} \mathrm{O}$} & $4.33(0.13)$ & & & \\
\hline & $4.09-4.58$ & & & \\
\hline \multirow[t]{2}{*}{$\mathrm{Y}$} & 245 (11.6) & $216(24.0)$ & 185 (15.5) & $170(17.3)$ \\
\hline & $228-226$ & $168-254$ & $155-215$ & $132-196$ \\
\hline \multirow[t]{2}{*}{$\mathrm{Zr}$} & $1930(77.1)$ & 1780 (189) & $1510(135)$ & $1430(115)$ \\
\hline & $1810-2060$ & $1360-2060$ & $1230-1830$ & $1200-1610$ \\
\hline \multirow[t]{2}{*}{$\mathrm{Nb}$} & $256(6.52)$ & $228(30.1)$ & $200(12.6)$ & $183(9.37)$ \\
\hline & $241-269$ & $179-275$ & $173-231$ & $150-193$ \\
\hline \multirow[t]{2}{*}{$\mathrm{Ba}$} & $93.6(4.65)$ & $75.0(26.7)$ & $110(6.53)$ & $101(6.19)$ \\
\hline & $87.0-102$ & $46.0-126$ & $90.9-119$ & $89.8-112$ \\
\hline \multirow[t]{2}{*}{$\mathrm{La}$} & $216(11.8)$ & $206(19.6)$ & 177 (17.1) & $168(17.3)$ \\
\hline & $197-238$ & $164-237$ & $142-217$ & $133-193$ \\
\hline \multirow[t]{2}{*}{$\mathrm{Hf}$} & $50.5(2.86)$ & $44.0(5.14)$ & $38.0(4.22)$ & $34.9(3.48)$ \\
\hline & $46.5-58.2$ & $32.9-51.8$ & $30.8-50.0$ & $30.0-41.7$ \\
\hline \multirow[t]{2}{*}{ Th } & $25.1(1.15)$ & $22.5(2.54)$ & $19.5(1.99)$ & $18.4(1.64)$ \\
\hline & $23.2-27.3$ & $17.7-26.5$ & $16.2-23.8$ & $15.7-21.7$ \\
\hline \multirow[t]{3}{*}{$\mathrm{U}$} & $6.81(0.58)$ & $6.26(1.18)$ & $5.975(0.51)$ & $5.12(0.33)$ \\
\hline & $6.09-8.71$ & $4.41-8.27$ & $4.89-6.99$ & $4.72-5.76$ \\
\hline & $\mathrm{n}=17$ & $\mathrm{n}=19$ & $\mathrm{n}=17$ & $\mathrm{n}=19$ \\
\hline
\end{tabular}




\section{REFERENCES CITED}

Akaike, H., 1998, Information Theory and an Extension of the Maximum Likelihood Principle, in Parzen, E., Tanabe, K., and Kitagawa, G. eds., Selected Papers of Hirotugu Akaike, New York, NY, Springer New York, p. 199-213, doi: 10.1007/978-1-4612-1694-0 15.

Blockley, S.P.E., Pyne-O’Donnell, S.D.F., Lowe, J.J., Matthews, I.P., Stone, A., Pollard, A.M., Turney, C.S.M., and Molyneux, E.G., 2005, A new and less destructive laboratory procedure for the physical separation of distal glass tephra shards from sediments: Quaternary Science Reviews, v. 24, p. 1952-1960, doi: 10.1016/j.quascirev.2004.12.008.

Bronk Ramsey, C., 2009, Bayesian analysis of radiocarbon dates: Radiocarbon, v. 51, p. 337-360.

Bronk Ramsey, C., 2008, Deposition models for chronological records: Quaternary Science Reviews, v. 27, p. $42-$ 60.

Bronk Ramsey, C., and Lee, S., 2013, Recent and planned development of the program OxCal: Radiocarbon, v. 55, p. $720-730$.

Connor, C.B., McBirney, A.R., and Furlan, C., 2006, What is the probability of an explosive eruption at a long dormant volcano, in Madder, H.M., Coles, S.G., Connor, C.B., and Connor, L.J. eds., The Geological Society of London, p. 39-46.

Connor, C.B., Sparks, R.S.J., Mason, R.M., Bonadonna, C., and Young, S.R., 2003, Exploring links between physical and probabilistic models of volcanic eruptions: The Soufrière Hills Volcano, Montserrat: Geophysical Research Letters, v. 30, doi: 10.1029/2003GL017384.

Davies, S.M., 2015, Cryptotephras: the revolution in correlation and precision dating: Journal of Quaternary Science, v. 30, p. 114-130, doi: 10.1002/jqs.2766.

Dzierma, Y., and Wehrmann, D., 2012, On the likelihood of future eruptions in the Chilean Southern Volcanic Zone: interpreting the past century's eruption record based on statistical analyses: Andean Geology, v. 39, p. 380-393.

Fierstein, J., and Nathenson, M., 1992, Another look at the calculation of fallout tephra volumes: Bulletin of Volcanology, v. 54, p. 156-167, doi: 10.1007/BF00278005.

Hutchison, W., Pyle, D.M., Mather, T.A., Yirgu, G., Biggs, J., Cohen, B.E., Barfod, D.N., and Lewi, E., 2016, The eruptive history and magmatic evolution of Aluto volcano: new insights into silicic peralkaline volcanism in the Ethiopian rift: Journal of Volcanology and Geothermal Research, v. 328, p. 9-33, doi: http://dx.doi.org/10.1016/j.jvolgeores.2016.09.010.

Jochum, K.P., Stoll, B., Herwig, K., Willbold, M., Hofmann, A.W., Amini, M., Aarburg, S., Abouchami, W., Hellebrand, E., Mocek, B., Raczek, I., Stracke, A., Alard, O., Bouman, C., et al., 2006, MPI-DING reference glasses for in situ microanalysis: New reference values for element concentrations and isotope ratios: Geochemistry, Geophysics, Geosystems, v. 7, p. 1-44, doi: 10.1029/2005GC001060.

Kassa, T.G., 2013, Holocene environmental history of Lake Chamo, South Ethiopia: University of Cologne.

Lamb, A.L., 2000, Stable Isotope Geochemistry of Lakes Tilo and Awassa, Ethiopia: a Holocene record of volcanic and climatic change: University of Wales Aberystwyth.

Lane, C.S., Cullen, V.L., White, D., Bramham-Law, C.W.F., and Smith, V.C., 2014, Cryptotephra as a dating and correlation tool in archaeology: Journal of Archaeological Science, v. 42, p. 42-50, doi: 10.1016/j.jas.2013.10.033.

Pearce, N.J.G., Abbott, P.M., and Martin-Jones, C., 2014, Microbeam methods for the analysis of glass in finegrained tephra deposits: a SMART perspective on current and future trends: Geological Society London Special Publications, v. 398, p. 29-46, http://sp.lyellcollection.org/content/early/2014/02/21/SP398.1.abstract\%5Cnpapers2://publication/doi/10.1144 /SP398.1.

Pearce, N.J.G., Perkins, W.T., Westgate, J.A., and Wade, S.C., 2011, Trace-element microanalysis by LA-ICP-MS: The quest for comprehensive chemical characterisation of single, sub- $10 \mu \mathrm{m}$ volcanic glass shards: Quaternary International, v. 246, p. 57-81, doi: 10.1016/j.quaint.2011.07.012.

Pearce, N.J.G., Westgate, J.A., and Perkins, W.T., 1996, Developments in the analysis of volcanic glass shards by laser ablation ICP-MS: quantitative and single internal standard-multielement methods: Quaternary International, v. 34-36, p. 213-227.

Peccerillo, A., Barberio, M.R., Yirgu, G., Ayalew, D., Barbieri, M., and Wu, T.W., 2003, Relationships between Mafic and Peralkaline Silicic Magmatism in Continental Rift Settings: a Petrological, Geochemical and Isotopic Study of the Gedemsa Volcano, Central Ethiopian Rift: Journal of Petrology, v. 44, p. 2003-2032, http://dx.doi.org/10.1093/petrology/egg068. 
Pyle, D.M., 1989, The thickness, volume and grainsize of tephra fall deposits: Bulletin of Volcanology, v. 51, p. 115, doi: 10.1007/BF01086757.

Rapprich, V., Žáček, V., Verner, K., Erban, V., Goslar, T., Bekele, Y., Legesa, F., Hroch, T., and Hejtmánková, P., 2016, Wendo Koshe Pumice: The latest Holocene silicic explosive eruption product of the Corbetti Volcanic System (Southern Ethiopia): Journal of Volcanology and Geothermal Research, v. 310, p. 159-171.

Reimer, P.J., Bard, E., Bayliss, A., Warren Beck, J., Blackwell, P.G., Bronk Ramsey, C., Buck, C.E., Cheng, H., Lawrence Edwards, R., Friedrich, M., Grootes, P.M., Guilderson, T.P., Haflidason, H., Hajdas, I., et al., 2013, IntCal13 and Marine13 radiocarbon age calibration curves 0-50,000 years cal BP: Radiocarbon, v. 55, p. 1869-1887, doi: 10.2458/azu_js_rc.55.16947.

Rethemeyer, J., Fülöp, R.-H., Höfle, S., Wacker, L., Heinze, S., Hajdas, I., Patt, U., König, S., Stapper, B., and Dewald, A., 2013, Status report on sample preparation facilities for 14C analysis at the new CologneAMS center: Nuclear Instruments and Methods in Physics Research B, v. 294, p. 168-172.

Siebert, L., Simkin, T., and Kimberly, P., 2010, Volcanoes of the World: Third Edition: University of California Press.

Swindles, G.T., Lawson, I.T., Savov, I.P., Connor, C.B., and Plunkett, G., 2011, A 7000 yr perspective on volcanic ash clouds affecting northern Europe: Geology, v. 39, p. 887-890, http://dx.doi.org/10.1130/G32146.1.

Taylor, R.P., Jackson, S.E., Longerich, H.P., and Webster, J.D., 1997, In situ trace-element analysis of individual silicate melt inclusions by laser ablation microprobe-inductively coupled plasma-mass spectrometry (LAMICP-MS): Geochimica et Cosmochimica Acta, v. 61, p. 2559-2567.

Telford, R.J., 1998, Diatom stratigraphies of Lake Awassa and Tilo, Ethiopia: Holocene records of groundwater variability and climate change: University of Wales Aberystwyth.

Telford, R.J., and Lamb, A.L., 1999, Groundwater-Mediated Response to Holocene Climatic Change Recorded by the Diatom Stratigraphy of an Ethiopian Crater Lake: Quaternary Research, v. 52, p. 63-75.

Telford, R.J., Lamb, H.F., and Umer, M., 1999, Diatom-derived palaeoconductivity estimates for Lake Awassa, Ethiopia: evidence for pulsed inflows of saline groundwater? Journal of Paleolimnology, v. 21, p. 409-421. 